\title{
FROM COLLISION TO COLLABORATION - INTEGRATING INFORMAL RECYCLERS AND RE-USE OPERATORS IN EUROPE: A REVIEW *
}

\author{
UDC 628.4(4-672EU)"2004/2016”
}

\author{
Anne Scheinberg ${ }^{1}$, Jelena Nesić ${ }^{2}$, Rachel Savain ${ }^{1}$, Pietro Luppi ${ }^{3}$, \\ Portia Sinnott ${ }^{4}$, Flaviu Petean ${ }^{5}$, Flaviu Pop ${ }^{5}$ \\ ${ }^{1}$ Springloop Cooperatie UA, Hague, The Netherlands \\ ${ }^{2}$ Democratic Transitions Initiative, Belgrade, Republic of Serbia \\ ${ }^{3}$ Zero Waste Brain Trust, Sebastopol, CA, USA \\ ${ }^{4}$ Occhio del Riciclone Italia ONLUS, Roma, ${ }^{5}$ Green Partners, Cluj-Napoca, Romania
}

\begin{abstract}
The European Union (EU) hosts some of the world's most developed waste management systems and an ambitious policy commitment to the Circular Economy. The existence of informal recycling and re-use activities in Europe has been vigorously denied until quite recently, and remains a very challenging subject for the European solid waste management sector, as well as for European government and private institutions. In countries ranging from Malta to Macedonia and from France to Turkey, informal recyclers excluded from legal recycling niches increasingly collide with formalised and controlled EU approaches to urban waste management, packaging recovery schemes, formal re-use enterprises, and extended producer responsibility systems.

This review focuses on the period from 2004 through the first half of 2016. The 78 sources on European (and neighbouring) informal recycling and re-use are contextualised with global sources and experience. The articles focus on informal recovery in and at the borders of the European Union, document the conflicts and collisions, and elaborate some constructive approaches towards legalisation, integration, and reconciliation. The overarching recommendation, to locate the issue of informal recovery and integration in the framework of the European Circular Economy Package, is supported by four specific pillars of an integration strategy: documentation, legalisation, occupational and enterprise recognition, and preparation for structural integration.
\end{abstract}

Key words: Informal Recycling and Re-use, Europe, Circular Economy, Balkans and New EU, Informal Integration, Extended Producer Responsibility.

Received July $23^{\text {rd }}, 2018$ / Accepted August $13^{\text {th }}, 2018$

Corresponding author: Anne Scheinberg, Springloop Cooperatie UA, Meidoornlaan 6, 8024 AX Zwolle,

The Netherlands

E-mail: ascheinberg@afval.org

"This article was previously published in: Scheinberg A., Nesić J., Savain R., Luppi P., Sinnott P., Petean F., Pop F.,

(2016). From collision to collaboration - Integrating informal recyclers and re-use operators in Europe: A review,

Waste Management \& Research, Vol. 34, No. 9, 2016, pp. 820-39. 


\section{INTRODUCTION}

Within and at the borders of the European Union (EU), home to the world's most developed and institutionalised waste management systems, and with an ambitious policy commitment to the Circular Economy, there are thousands, possibly millions of informal recyclers and re-use operators. The existence of informal recovery activities in Europe, and the corresponding need for informal sector legalisation and integration in Europe, has been vigorously denied until quite recently, and remains a very challenging subject for the European solid waste management sector. European government and private institutions, in charge of municipal cleansing and hygiene, see the informal sector as undermining their work and creating dangerous risks for public health and safety. Informal recyclers and re-use operators seldom have a legal status, and themselves feel that the economic niches that support them and their families are being eliminated without offering them an alternative. Clashes and conflicts are growing, and some form of co-ordinated action will be necessary if the European ambitions for resource efficiency are to become a reality (European Commission (EC) 2016a, 2016b European Environmental Agency (EEA) 2009, Eurostat 2015, Len 2014).

\section{The Context: Recycling in the European Union and the Balkans}

In Europe, the general approach to re-use and recycling is that they are part of the waste management sector, they are priorities in EU policy, and that they "belong" to governmental institutions who rely on them to achieve policy targets. Service chain institutions in Europe see their responsibilities as covering separation rules for households, set-out of waste and recycling, collection, transfer and storage, and processing, recycling, recovery and disposal of waste, bio-waste re-usables, and recyclables. Renewed focus on waste prevention takes this responsibility "upstream" to include influencing packaging and consumption choices.

The modernized European waste collection system is regulated by the Waste Framework Directive 2008/98/EC (EC 2008). All EU member states and pre-accession countries use the directive as a guide. Higher levels of the solid waste hierarchy - such as waste prevention, re-use, and recycling - have a higher priority in policy, but are outside of the purview of municipal cleansing institutions, and as a result are implemented unevenly. Important changes approved in April 2016 in the framework of the European Circular Economy Package introduce a robust set of reforms that give even more priority to reducing the production of waste, redesigning and diverting products and packages from disposal (ACR+ 2009, Len 2014, Luppi and Sole 2015, EC 2016a, EC 2016b, EEA 2009, Eurostat 2015, Zambryzcki 2013).

The EU waste and materials policy framework - and the new requirements of the Circular Economy Package -- require producers to manage the end of life of their products and packages. The three principal directives for packaging waste, chemicals, and electronics, regulate the management of the end of life of produces and packages in a sustainable way, largely through ensuring recycling and safe disposal. This highly developed, dynamic, and institutionalised approach to waste and materials management creates an entirely different context for informal re-use and recycling in Europe than for similar activities in Asia, Latin America, and Africa (ACR+ 2009, EC 2016a, EC 2016b, Zero Waste Europe 2015, EEA 2009, Ramusch et al. 2015, Scheinberg and Nesić 2014).

Most of the countries at the borders of the EU are in the process of becoming member states or of affiliating with the EU at some institutional level. The process of "accession" to 
the European Union requires wide-ranging measures to "harmonise" governance, legal and regulatory systems and bureaucratic culture with the requirements for EU member states. Solid waste systems in Macedonia, Serbia, Bosnia-Herzegovina, Montenegro, Turkey, and Kosovo, are all being modernised in the framework of the EU accession and harmonisation process, just as occurred previously in Slovenia, Croatia, Bulgaria and Romania. Formal institutions in the waste management sector in Europe have been increasingly required to take responsibility for the entire waste cycle, including prevention and recycling. This has taken 30 years in the "old EU," but must occur rapidly in countries seeking accession to the EU. This brings far-reaching changes to three main institutional landscapes: the service chain businesses and public institutions responsible for city cleaning and waste collection; the value chain of recycling traders and processors that are closely connected to global materials chains in Asia and elsewhere; and producers, importers, wholesalers, distributors, and retailers of consumer goods and packaging (DTI 2013, EC 2016a, EC 2016b, ACR+ 2009, Belghazi 2008, Scheinberg and Mol 2010, Scheinberg and Savain 2015, Soos and Popoviçi 2008, Schmied et al. 2011, Doychinov 2008, Doychinov and Whiteman 2013, Newman 2015).

As the pre-accession period progresses, cities and national ministries in South-eastern Europe, Turkey, Tunisia, and other countries under EU policy influence, come to understand that they are now required to take responsibility for organising recycling and promoting prevention and re-use. With some exceptions, "recycling" is something that is new - and uncomfortable - for municipal authorities, whose public cleansing companies have focused on removing waste and cleaning streets. They seldom realise that "recycling" is above all a private value chain activity. They lack experience, contacts, expertise - and above all interest - in entering the complex and highly commercialised world of trading materials in the value chain. And they do not realise that the informal street pickers and reuse entrepreneurs who work the streets at 6 am, are the primary suppliers to a globalised recycling system. Nor does it occur to these public actors, that informal activities may already be meeting or exceeding the goals set by EU directives for recycling and recovery (Ramusch et al. 2015, Scheinberg et al. 2010b, Belghazi 2008, Luppi and Sole 2015, Toska and Lazarov 2007, Toska et al. 2012, DTI 2013, EEA 2011, Gunsilius et al. 2011, Vaccari et al. 2013, Wilson et al. 2006, Scheinberg and Mol 2010, Chikarmane and Narayan 2009, Scheinberg et al. 2007, Simpson-Hébert et al. 2005).

The situation for producers of products and packages is also uncomfortable. For them, the responsibility for end of life management is new: until relatively recently, they were responsible only for the "front end" of the life cycle, producing and selling, and not for the "back end," collection, processing, and recycling or end-of-life management. Especially in the new EU (Romania, Bulgaria, Croatia, Slovenia) and in pre-accession countries such as Turkey and former Yugoslav republics, producers are under pressure to organise packaging recovery systems. Even though producers active in these countries know how the value chains work, they often do not "see" informal recyclers and re-use operators as being critical to the entire recycling system (Zero Waste Europe 2015, OECD 2016, EXPRA 2014, see also Box 3 and Box 4, below).

\section{Historical Overview: Scholarship and Practice on Informal Recycling, Re-use and Waste Management Outside of Europe.}

Table 1 describes how informal recycling came to the attention of the international community. The push came from some European development co-operation organizations, especially those of Germany and the Netherlands, the Collaborative Working Group on 
Solid Waste Management in Low- and Middle-income Countries (the CWG), the World Bank, social development initiatives in Egypt and India, the child labour elimination initiatives of the International Labor Organization (ILO), and the focus on member-based organisations of waste pickers by WIEGO (Women in the Informal Economy, Globalising, Organising). (ILO 2004, Chen 2012, Scheinberg and Anschütz 2006, Cohen et al. 2013).

Table 1 Insights from International Sources on Informal Recycling

\begin{tabular}{|c|c|c|}
\hline Insights & First Wave- 1990s & Second Wave-2000s \\
\hline $\begin{array}{l}\text { Informal } \\
\text { Recyclers } \\
\text { and their } \\
\text { activities }\end{array}$ & $\begin{array}{l}\text { - informal recyclers choose activity due } \\
\text { to lack of formal education or } \\
\text { paperwork } \\
\text { - eliminating children's participation } \\
\text { requires parental and community } \\
\text { involvement in decision making } \\
\text { - often more interested in improving } \\
\text { their business model than in "better } \\
\text { work" } \\
\text { - either waste pickers do the activity for } \\
\text { less than } 6 \text { months or a lifetime, } \\
\text { involving multiple generations }\end{array}$ & $\begin{array}{l}\text { - informal recyclers make up as much as } 1 \% \\
\text { of the world population - large numbers are } \\
\text { in Asian, Latin American, and North } \\
\text { American cities } \\
\text { - formalisation trends favour men } \\
\text { - informal recyclers perform environmental } \\
\text { services for their cities, some of which can } \\
\text { be quantified and generate value that cities } \\
\text { do not pay for or support }\end{array}$ \\
\hline $\begin{array}{l}\text { Informal } \\
\text { Recycling } \\
\text { Systems }\end{array}$ & $\begin{array}{l}\text { - earnings often surpass minimum wage } \\
\text { - privatised landfills and waste } \\
\text { collection disrupt informal livelihoods } \\
\text { - International and charity efforts to } \\
\text { move waste pickers out of the system } \\
\text { fall short because the profits are not } \\
\text { comparable. }\end{array}$ & $\begin{array}{l}\text { - in most developing country cities the } \\
\text { majority of recycling happens informally } \\
\text { - more people work in the informal waste } \\
\text { sector than the formal } \\
\text { - European cities have active informal systems } \\
\text { - pro-forma costs of informal recycling and } \\
\text { waste collection are lower formal service costs. } \\
\text { - formalising and legalizing informal recycling } \\
\text { depends on social and governance factors, } \\
\text { including the establishment of identity of } \\
\text { internal or cross-border migrants }\end{array}$ \\
\hline
\end{tabular}

Informal recyclers live by primary extraction of discarded items and materials from disposal sites, streets, containers, and sometimes directly from generators. They valorise these materials and products, and sell them to the value chains. They support themselves and their families with the income from trading. Informal sector issues began to enter into the mainstream waste management discourse on developing countries starting around 2006, partially stimulated by the periodic workshops of the Collaborative Working group for Solid Waste Management in Low- and Middle-income Countries (the CWG), and the study "Economic Aspects of the Informal Sector in Solid Waste" financed by GIZ (German International Co-operation, at the time referred to as GTZ, German Technical Co-operation) (Scheinberg et al 2010b). Since then, there has been a growing literature on informal recycling in developing countries, and a robust body of practice on integrating informal recyclers into formal systems in Latin America, Asia, and North Africa.

According to a number of studies, dating back to 2006, this form of work keeps many tonnes of waste out of landfills, saves cities and households money, reduces greenhouse gas formation, and supports millions of families worldwide (Medina 2009, Chikarmane 
and Narayan 2009, Gunsilius et al. 2011, Chaturvedi 2009, Linzner 2012, Wilson et al. 2009, Linzner and Lange 2013, Linzner et al. 2011, Scheinberg et al. 2010b, Wilson et al. 2010, Wilson et al. 2015).

Outside of Europe, the existence and importance of waste picking is gradually becoming accepted by the waste management industry, forward-looking producers, and a number of multi-lateral institutions including the World Bank, the International Finance Corporation, and the InterAmerican Development Bank. Informal activity has achieved the status of an uncomfortable but inescapable reality, that has to be considered in plans to upgrade waste management (Scheinberg et al. 2010a, 2010b, Wilson et al. 2006, Wilson et al. 2010, Velis et al. 2012, Cohen et al. 2013, Scheinberg and Savain 2015, Ramusch et al. 2015, Wilson et al. 2009, Popovska 2008).

In middle-income countries with very large populations of informal recyclers, such as Brazil, South Africa, Colombia, China, Indonesia and India, conflicts and competition for materials have led to a body of advocacy, research, and projects on integrating the informal sector into processes of modernisation of waste management systems. Legalisation and integration generally depend on a demand for informal recyclers to organise themselves in co-operatives, unions and/or associations, register, pay taxes, and operate legally within the framework of the service chain (waste collection and disposal) or the value chain (recycling industries). Informal integration refers to a situation where recycling is a recognised official occupation, and informal recyclers have a legal identity, are protected by laws and decrees, covered by social protection schemes, and, increasingly, paid for the value of the service they are delivering to the city and the environment (Dias 2006, Gunsilius et al. 2011, Chaturvedi 2009, CEMPRE 2014, Rutkowski and Rutkowski 2015, Godfrey 2014, Chikarmane and Narayan 2009, Medina 2009).

But there has been little willingness to acknowledge that informal activities are also affecting solid waste and recycling systems in middle, upper-middle, and high-income countries in North America Oceania, and high-income Asia, and in Europe. The EXPRA/RDN/ISWA meeting in Bucharest in 2014 was one of the first international meetings to break that taboo, and to engage in a discussion of conflicts between formal and informal recycling activities in and at the borders of the EU (EXPRA 2014, OECD 2016, Linzner 2012, Linzner and Lange 2013, Schmied et al. 2011, Velis et al. 2012, Cohen et al. 2013, Scheinberg and Savain 2015, Ramusch et al. 2015, Wilson et al. 2009).

\section{Collisions in the Making}

There are many more informal recyclers in Europe than is generally acknowledged, and their recovery activities are undermining EU-harmonised recycling, re-use, waste management and producer responsibility systems. Informal recycling and re-use activities are like double-edged sword: on the one hand they are seen as the cause of health, safety, and environmental problems, and on the other, they are a significant resource for cities and regions to meet or exceed ambitious EU recovery and diversion targets. Packaging schemes in Turkey and the Balkans are "losing" target materials, seeing them pass through informal hands and diminishing the value of investments in modern packaging systems (EXPRA 2014, Eröztürk 2015, Springloop Cooperatie 2016).

And the converse is also true: informal recycling and re-use operators are encountering increasing competition for recyclable and re-usable materials coming from formal recycling and re-use systems, and their spaces for legal operation are closing. Also in the re-use sector, formal or semi-formal second-hand shops, flea markets, and charitable institutions are seeking 
to de-legitimise informal re-use operators and pop-up flea markets, stimulating a struggle for rights to continue to commercialise re-usables (Soos and Popoviçi 2008, IFC 2010, Linzner 2012, Obersteiner et al. 2012, Len 2014, DTI 2013, EXPRA 2014, Kozák 2012, Luppi and Sole 2015, Zero Waste Europe 2015).

Conflicts are emerging in interactions between informal re-use and recycling sectors and three sets of formal institutions:

- The service chain, consisting of public and private waste companies, intergovernmental entities and public sector operators;

- National ministries and institutions in the areas of social affairs, economics, migration, labour, and commerce;

- Producers of consumer goods and packaging, and the extended producer responsibility (EPR) institutions and organisations that represent them.

Waste management companies have difficulty with the fact that street pickers "make a mess" when extracting valuable materials from waste set-outs or containers, making their work more difficult. Conflicts with private waste companies arise in countries like Austria or Colombia where private waste collection is paid by the tonne and then the companies say that waste pickers are "stealing the waste," even when the households make a decision to give their washing machines or old clothes to an informal re-use entrepreneur or to someone collecting to sell at the flea market. Waste industry trade associations also note that "invasion" of landfills by dump pickers makes these landfills unsafe and unsanitary (Schmied et al. 2011, Scheinberg 2011, Newman 2015).

The collision with governmental and para-statal institutions is based on the governance of social norms and labour protections. United Nations organisations such as the International Labour Organization (ILO) and the International Trade Union Confederation (ITUC) have well-documented objections to the presence of children picking waste on landfills or in containers, but they have a more nuanced view of the position of adult independent recyclers. These and other organizations work to create social and health protections, reduce the risk of disease and injury in the recycling sector, and organize pickers in solidarity institutions such as labour unions or co-operatives. They also generally support the professionalisation and occupational recognition of waste picking (ILO 2004, Chikarmane et al. 2008, Scheinberg and Anschütz 2006, ITUC 2014).

The third, and perhaps the most dramatic set of confrontations, comes when waste pickers harvest discarded packaging wastes and wastes from electric and electronic equipment (WEEE) which are covered by packaging or e-waste collection and Extended Producer Responsibility (EPR) schemes. These systems enjoy robust levels of capitalization and political support, but, due to large and active groups of informal recyclers and reuse operators, have been documented to capture less than $10 \%$ of total recyclables collected in countries like Bulgaria, Slovenia, Turkey, Malta, and Greece (EXPRA 2014, Scheinberg and Nesić 2014, OECD 2016).

Discomfort also characterises relations between informal re-use operators and recyclers and two additional sets of (semi-)formal stakeholders (Luppi and Sole 2015, Len 2012):

- the value chains, that is, private recycling and re-use firms, who buy the materials, and

- civil society, including social enterprises, community-based organisations, environmental non-governmental organisations (NGOs) and charitable institutions. 
Waste pickers and informal recyclers and re-use operators sell their materials to small and medium-sized junk shops, antique and second-hand shops, and sometimes also larger dealers, exporters, and end-users. Waste pickers depend on these enterprises, but often express a view that the prices are less than fair. There is clear need for improving existing co-operation, rather than a collision. Improving waste picker relationships and recycling performance through interventions in value chains have been studied in detail in a number of countries, most recently in Central America and North Africa, but also in the Balkans (Lobo Ugalde et al. 2016, Popovska et al. 2008, Soos et al. 2014, Scheinberg et al. 2007).

There is frequently a disconnect between informal recyclers and re-use operators in Europe, and NGOs involved in charitable re-use shops, social enterprises, community development and environmental activism. Social enterprises dominate the European reuse sector, and community development and environmental NGO's are abundantly present in some countries like the UK, in the area of packaging and recycling. These organisations have an uncomfortable relationship with the informal sector, which they would prefer to eliminate, but often settle for focusing on social entrepreneurship and/or "recycling projects" (Rutkowski and Rutkowski 2015, Oyake-Ombis 2012, Len 2012).

\section{Structure of this Article}

This introduction (Section 1) provides an orientation to the body of work - scholarship, policy advocacy, and practice - on informal recycling and re-use in Europe, lightly contextualised with historical and global information. Section 2, following, reviews sources that document and characterise informal recycling and re-use activities in Europe, as well as projects, initiatives and structural interventions ranging from traceability requirements to union organising. The third and final section does some light classification of the sources, draws out some insights from the review, and suggests conclusions and courses of action that can be derived from these sources.

\section{EUROPEAN INFORMAL RECYCLING AND RE-USE, A REVIEW}

This section of the paper reviews the state of informal recycling in Europe using the approaches and (evolving) vocabulary that has characterised work in low- and middleincome countries outside of Europe. This review focuses on the 78 entries in the reference list that make a specific reference to European informal re-use and recycling:

1. sources documenting and characterising informal recyclers and re-use operators in Europe:

2. sources introducing the collision course between informal recyclers and re-use operators, and formal stakeholders; and

3. sources presenting initiatives, projects and approaches to informal legalisation and integration solutions.

The sources fall into four categories, including

1. scholarly article, action research or student report, conference, project report,

2. social or labour advocacy and/or organising,

3. policy documents, laws, government, donor consultant reports, plans, and

4. direct information provided by individuals or organisations working on informal recycling and re-use in Europe. 


\section{Documenting Informal Recyclers and Re-use Operators in Europe.}

Practitioners and researchers in the recycling and waste management sectors began researching and documenting Europe's informal recycling sector between 1998 and 2008. One of the earliest available sources highlighting repair for re-use is a small handbook, Rubber Recycling, published in 1996. This document describes research on informal rubber recycling micro-enterprises in Naples, Italy, called gomnisti, who operate several levels of re-use, repair, and reprocessing. The earlier literature generally limits itself to the social issues, showing that waste pickers are members of vulnerable groups within the European society. Later articles treat operational questions, and begin the integration discourse by illustrating the practical, operational, social and environmental benefits created by waste pickers and informal re-users (Ahmed et al. 1996, Simpson-Hébert et al. 2005, Luppi 2006, Occhio del Riciclone 2006, Occhio del Riciclone 2007, Conseil De L'Europe 2013, Fernandez and Ruberto 2008, Popovska et al. 2008, Soos and Popoviçi 2008).

Italian informal re-use operators have been a major focus of research, activism, lobbying, and interventions at the Economic and Social Research Centre of Occhio del Riciclone (OdR, in English: Eye of the Re-cyclone). This rich source of information and analysis of the Italian re-use sector began with a consultation in 2003 with several hundred informal re-use operators active in the city of Rome, using a survey designed by a group of economists, communication experts and environmental technology specialists. The City of Rome awarded its Environment and Development prize for the study focusing on Rome, one of a group of cities studied, that included Anguillara, Ciampino, Udine, Vicenza, and Empoli (Luppi 2006, Occhio del Riciclone 2006, 2008, 2009). Working with OdR In 2008, WIEGO, the global charity Women in the Informal Economy Globalising Organising, co-financed a focused study on informal re-use in Rome (Fernandez and Ruberto 2008).

Box 1 Eurostat Mentions Informal Recyclers' Contributions

"The informal sector manifests itself in different ways in different countries, different regions within the same country, and even different parts of the same city. It encompasses different kinds of activities, different types of enterprise, and different reasons for participating. Informal activities range from street vending, shoe shining, food processing and other minor activities requiring little or no capital and skills and with marginal output, to those involving a certain amount of investment in skills and capital and with higher productivity, such as manufacturing, tailoring, car repair and mechanised transport. While some informal sector activities resemble traditional activities in handicrafts, food processing or personal services, others such as car repair, recycling of waste materials or transport, are new and arise from modernisation.

Reasons for participating in the informal sector range from pure survival strategies undertaken by individuals facing a lack of (adequate) jobs, unemployment insurance or other forms of income maintenance, to the desire for independence and flexible work arrangements and, in some cases, the prospect of quite profitable income-earning opportunities, or the continuation of traditional activities.

"It should be noted that the vast majority of informal sector activities provide goods and services whose production and distribution are perfectly legal (in contrast to criminal activities or illegal production). There is also a difference between the concept of the informal sector and that of the hidden or underground economy, because informal sector activities are not necessarily performed with the deliberate intention of evading the payment of taxes or social security, but to reduce production costs."

Source: Eurostat (2015), emphasis added.

The authors believe that the first focused treatment of informal recycling in Europe was in the ILO Desk Study in 2004, with contributions by an action research team that worked with Romanian informal recyclers. This study discovered that interventions in what is now called 
"social integration" had generally failed to improve lives and livelihoods of waste pickers, and hypothesised that treating informal recyclers as recycling entrepreneurs with important skills and knowledge would lead to the formulation of a different kind of intervention, based on professionalising their recycling activities to improve working conditions and income levels (ILO 2004, Scheinberg and Anschütz 2006).

The definitive monograph on informal recycling in former Yugoslavia, "A Paper Life", by Mayling Simpson-Hébert, Alexandra Mitrović, Gradimir Zajić and Milos Petrović, documents waste picking in former Yugoslavia in a period before EU influence began to affect solid waste planning and practice. Available in Serbian and English, this small book provides a clear and immensely valuable baseline on European waste picking in the Balkans in a period when state socialist municipal waste institutions, the "Čistoća" or "Javno Komunalno Preduzece" still had a functional monopoly in the service chain (Simpson-Hébert et al. 2005).

The Belgrade waste pickers interviewed were primarily recycling paper and cardboard, non-ferrous metals, car parts, and re-usables. The monograph documents a state of mutual tolerance and understanding, so stable that waste pickers are quoted as saying, in response to questions about legality of waste picking "So far it has not been prohibited" or "As long as the dumps exist - that means that this work of ours is allowed." Waste pickers also reported that before the Vinca Dump in Belgrade was closed, they were not only tolerated, but garbage truck drivers would let Roma community members ride with them on their way to school or the city (Simpson-Hébert et al. 2005, Scheinberg et al. 2007).

The MIREA (Mainstreaming, Informal Recyclers in Europe and Africa) proposal to Europe-Aid was the occasion for several European organisations working in five European Union and pre-accession countries to establish an inventory of waste picking, including an inventory of occupations and an estimate of numbers of informal recyclers and re-use operators, in these countries.

The city of Cluj-Napoca in Northern Romania was selected as one of the six cities in the GIZ informal sector study and represents one of the earliest attempts to document "informal integration" in a European city. The City Report for Cluj-Napoca compared the performance, costs, and capture rates of informal recyclers at the Pata Rat landfill in ClujNapoca, with those of the formal European Union co-financed EcoRom packaging system, and concluded that informal recyclers were recovering many tonnes of materials at a fraction of the costs per tonne of the EcoRom system. They were providing a substantial positive environmental contribution to the city, but working in very poor and unhealthy conditions. The private waste company operating the landfill was interested in co-operation with the informal recyclers; in contrast, the city authorities, even when they understood that they benefitted from informal activities, were not willing to engage in dialogue (Soos and Popoviçi 2007, Soos and Popoviçi 2008, Scheinberg et al. 2010b, Gunsilius et al. 2011, Scheinberg and Mol 2010, Popovska et al. 2008, Tasheva 2012, Toska et al. 2012, Whiteman et al. 2009). 
Table 2 Global informal occupations as documented in Europe

\begin{tabular}{|c|c|c|}
\hline $\begin{array}{l}\text { Global } \\
\text { occupation }\end{array}$ & Global features found in Europe & $\begin{array}{l}\text { Specific variations or characteristics } \\
\text { found in Europe }\end{array}$ \\
\hline $\begin{array}{l}\text { Occupation } 1 \\
\text { waste pickers } \\
\text { (WPs): }\end{array}$ & $\begin{array}{l}\text { Collect materials on foot or with } \\
\text { tricycle or motorcycle with cart from } \\
\text { street set-outs, containers, illegal and } \\
\text { legal dumps. }\end{array}$ & $\begin{array}{l}\text { European waste pickers pick both } \\
\text { recyclables and re-usables, and do not } \\
\text { usually specialise. }\end{array}$ \\
\hline $\begin{array}{l}\text { Occupation } 2, \\
\text { itinerant waste } \\
\text { buyers/collectors } \\
\text { (IWBs/IWCs). }\end{array}$ & $\begin{array}{l}\text { IWBs move along a route and trade } \\
\text { directly with household and business } \\
\text { waste generators, buying recyclables } \\
\text { and offering a private separate } \\
\text { collection service. }\end{array}$ & $\begin{array}{l}\text { In Europe IWCs are more likely to get } \\
\text { the materials "as a donation". } \\
\text { A European variation is also to perform } \\
\text { some paid service, like cleaning out an } \\
\text { attic or helping with moving house, and } \\
\text { have the right to take materials }\end{array}$ \\
\hline $\begin{array}{l}\text { Occupation } 3, \\
\text { small dealers, or } \\
\text { small junk shops }\end{array}$ & $\begin{array}{l}\text { The first level of mobile or stationary } \\
\text { traders who buy from waste pickers } \\
\text { and IWB/IWCs. Premises are often } \\
\text { without permits, and attract fines from } \\
\text { zoning officers. }\end{array}$ & $\begin{array}{l}\text { A European variant is second-hand } \\
\text { traders, who buy and upgrade or repair } \\
\text { materials, evaluate whether they can } \\
\text { market them into the upper levels to } \\
\text { antique markets, and then sell them. }\end{array}$ \\
\hline $\begin{array}{l}\text { Occupation } 4, \\
\text { second-hand } \\
\text { operators }\end{array}$ & $\begin{array}{l}\text { Not considered part of the informal } \\
\text { recycling sector in countries like } \\
\text { Brazil or India, although picking of } \\
\text { re-usables for own use is a common } \\
\text { supplement to waste picking for } \\
\text { recycling }\end{array}$ & $\begin{array}{l}\text { In Europe re-usables are picked by } \\
\text { street and container pickers, IWCs, } \\
\text { traders, transporters, and merchants, } \\
\text { and includes merchants specialised in } \\
\text { direct sales of re-usables via pop-up } \\
\text { flea markets, stalls in formal markets, } \\
\text { and concession shops. }\end{array}$ \\
\hline $\begin{array}{l}\text { Occupation } 5, \\
\text { swill collectors, } \\
\text { herders }\end{array}$ & $\begin{array}{l}\text { Collectors of food waste and spent } \\
\text { frying oil for animal feeding or soap. } \\
\text { A common variant is to graze } \\
\text { livestock on official dumpsites or } \\
\text { unofficial waste heaps. }\end{array}$ & $\begin{array}{l}\text { Grazing of pigs on village dumps, is } \\
\text { common. Swill or spent oil collection } \\
\text { in Europe is usually an activity of the } \\
\text { formal, rather than the informal, sector. }\end{array}$ \\
\hline
\end{tabular}

The 2011 MSc thesis and resulting publication of Natasha Sim, on informal recycling in Bishkek, Kyrgyzstan (considered as lightly in the EU influence sphere), indicates that Central Asian informal recycling and re-use is similar to that in Europe, and that the formal authorities there are equally hostile to the ideas of integration. The study suggests that the informal sector in that city is recycling $18 \%$ of the waste, at no cost to the city, but generating positive financial benefits calculated as annual savings of US\$1 million through savings in collection and disposal of waste (Sim et al 2013). 
Table 3 Numbers of Informal Recyclers and Re-use Operators in Six European Countries

\begin{tabular}{|c|c|c|}
\hline $\begin{array}{l}\text { City and } \\
\text { country }\end{array}$ & Census information/estimates & Occupations and level of organising \\
\hline $\begin{array}{l}\text { Sofia, } \\
\text { Bulgaria }\end{array}$ & $\begin{array}{l}\text { Diverse group of at least } 2,000 \text { pickers in } \\
\text { Sofia. Roma men, and women and their } \\
\text { young children, waste pick at non- } \\
\text { compliant dumpsites near bigger towns. }\end{array}$ & $\begin{array}{l}\text { Most active in Occupations } 1 \text { and } 2 \text {. No } \\
\text { organising is reported, although two } \\
\text { Roma social development organisations } \\
\text { worked on this } 1990 \mathrm{~s}\end{array}$ \\
\hline $\begin{array}{l}\text { Attica Region } \\
\text { (including } \\
\text { Athens), } \\
\text { Greece, half } \\
\text { the country's } \\
\text { population }\end{array}$ & $\begin{array}{l}\text { Approximately } 25,000-50,000 \text { waste } \\
\text { pickers regionally, as many as } 100,000 \\
\text { in Greece, including part-time and } \\
\text { seasonal pickers. Estimated } 40 \% \\
\text { increase in waste picking since the } \\
\text { economic crisis. }\end{array}$ & $\begin{array}{l}\text { The oldest waste pickers association of } \\
1,185 \text { persons, that are self described as } \\
\text { "mostly Muslim Greeks" mainly active } \\
\text { in occupations } 1 \text { and } 4 \text {, with some } \\
\text { reporting of occupation }\end{array}$ \\
\hline $\begin{array}{l}\text { Rome and } \\
\text { other major } \\
\text { cities, Italy }\end{array}$ & $\begin{array}{l}60,000 \text { to } 80,000 \text { operators work in the } \\
\text { informal re-use trade, in occupation } 4 \text {. } \\
\text { Their involvement in metal and plastic } \\
\text { recycling, usually associated with } \\
\text { occupation } 1, \text { is occasional. }\end{array}$ & $\begin{array}{l}1100 \text { are organised reuse traders and } \\
\text { members of Rete ONU, primarily in } \\
\text { occupation } 4 \text {, with some activities } \\
\text { associated with occupations } 1 \text { and } 2 .\end{array}$ \\
\hline $\begin{array}{l}\text { Skopje, } \\
\text { Macedonia }\end{array}$ & $\begin{array}{l}5,000 \text { street } \& \text { dump pickers active in } \\
\text { occupations } 1,2 \text {, and } 3 \text { were identified } \\
\text { by a USAID project }\end{array}$ & $\begin{array}{l}\text { A subset were organised into co- } \\
\text { operatives between } 2005 \text { and } 2013\end{array}$ \\
\hline $\begin{array}{l}\text { Bucharest, } \\
\text { Romania }\end{array}$ & $\begin{array}{l}1.000 \text { street pickers collect aluminium } \\
\text { used beverage containers (UBC). Collect } \\
\text { from apartments, offices open markets, } \\
\text { litter bins, parks. Of these, } 10 \% \text { are } \\
\text { regarded as "professionals" (working } \\
\text { longer hours, collecting consistently } \\
\text { more materials, and having better } \\
\text { equipment, etc.) } 80 \% \text { are "full-timers", } \\
\text { and } 10 \% \text { are "part timers." }\end{array}$ & $\begin{array}{l}\text { The informal sector is unorganised, and } \\
\text { there are no functioning associations, } \\
\text { cooperatives, or unions of informal } \\
\text { recyclers in Romania and no visible } \\
\text { actors within civil society defending } \\
\text { their rights. Most waste pickers involved } \\
\text { in occupation } 1\end{array}$ \\
\hline $\begin{array}{l}\text { Belgrade \& } \\
\text { other cities in } \\
\text { South, Serbia } \\
\text { (former } \\
\text { Yugoslavia) }\end{array}$ & $\begin{array}{l}5,000 \text { to } 15,000 \text { disposal site and } \\
\text { container pickers "collectors" - Roma } \\
\text { men, many refugees from Kosovo }\end{array}$ & $\begin{array}{l}\text { Social integration and education for } \\
\text { Roma communities supported by } \\
\text { UNICEF and a syndicate (union) based } \\
\text { in the South Serbian city of Niš. Most } \\
\text { waste pickers active in occupations 1, 2, } \\
\text { and 3, and WEEE interest growing }\end{array}$ \\
\hline
\end{tabular}

The action research project "Engaging Informal Recyclers in Europe" received seed money from WIEGO in 2012, and was designed around consultations, casual meetings with groups of informal recyclers on landfills, in their communities, or, when they are already involved in projects, as is the case in Macedonia and Serbia. Consultations were held in Serbia, Bosnia, Montenegro, Macedonia, Italy and Greece, with the goal of establishing a base of information and identifying the main issues facing the collectors. In most cases the informal recyclers expressed their interests in the directions of sociopolitical integration, value chain optimisation, and inclusive EPR. The general reactions to business-based integration approaches were positive, but there was little interest expressed in forming co-operatives or social enterprises (Scheinberg and Nesić 2014, Conseil de L'Europe 2013). 


\section{Documenting the Collision Course between Informal and Formal Recycling Stakeholders.}

The informal recycling operations in Europe seem to be on a collision course with EU approaches, institutions, and professional bodies working in the solid waste sector, in ministries of labour and social affairs, and in relation to extended producer responsibility (EPR) organisations and systems. This section focuses in on some of the collisions.

\footnotetext{
Box 2 Resistance: Organising Re-use operators at the Porta Portese Market In 2009 a large number of the displaced (Roma) operators forced their way into conducting business in the Porta Portese Market, creating new incidents of destabilization and conflict with the deeply rooted local operators. The leaders of the market went to the levels of individual operators, and calming micro-conflicts, in their commitment to facilitate dialogue, ultimately solving the conflict. The leaders explained to each of the operators that a "war among the poor" would help no-one and hurt everyone, and they emphasized common interests and the need for everyone to benefit from solutions. This resulted in Italian and Roma itinerant operators jointly advocating a transparent and fair system for giving concessions in public spaces in the city. This experience contributed to the formation of "Rete ONU," the national network of second-hand operators which unites all of segments of the Italian second-hand sector, and includes Rome and Italian operators. It succeeded in establishing an official dialogue with the national government and is working actively with the national congress to improve legislation.

In 2016, this unified group of re-use operators was able to produce a methodology for valuating re-use activities, based on life cycle assessment (LCA) methods developed by the group Mercatino SRL (Occhio di Riciclone 2015). On the basis of this method, the Turin city authorities made a formal decision to recognise and support re-use operators with concessions and allowing them to dispose of residues at a reduced price.

Source: Adapted by the authors from Luppi and Sole (2015); Occhio del Riciclone and Associazione Operatori Porta Portese (2006); Occhio del Riciclone (2009); Occhio del Riciclone \& Ministero dell'Ambiente (2011); Torino City Hall and Rete ONU (2016).
}

\section{Collisions between informal recyclers and EU-supported packaging recovery}

As the highly transparent, organised, institutionalised, and technology-intensive EU approach to service chain recycling spreads to the new EU, former Yugoslavia, and neighbouring (pre-accession) countries such as Albania, Turkey and Moldova, spaces for informal activity close, often in parallel with economic reforms that lead to fewer opportunities for formal employment (Conseil de l'Europe 2013, Whiteman et al. 2009, Whiteman 2008, Soos and Popoviçi 2008). Those whom the labour system cannot absorb, and who are unable to survive in formal economic niches, face loss of livelihood, and have to depend on social welfare systems, at a time when these are also disappearing. This analysis is particularly relevant for understanding informal recycling (and re-use) enterprises in the EU and in the pipeline to join it, and it explains in part why the level of confrontation between waste pickers and local and national authorities seems higher - and more complex to resolve - than in other parts of the world (Luppi and Vergalito 2013).

Waste picking and informal recovery in Europe have a long history of co-production (as well as co-evolution) with the public cleansing companies, and rag-and-bone picking appear in waste management articles about the $19^{\text {th }}$ century, and waste picking was legalised in Paris in the 1200s, only to be forbidden again in the 1960s. The current levels of conflict have emerged gradually, as the European Union has financed and supported the modernisation of its member countries and their waste management systems, which 
pushes local and national authorities to divert increasing amounts of waste from disposal to recovery (Melosi 1981, Gutberlet 2008, Velis et al. 2009, de Swaan 1988, Poulussen 1987, Scheinberg 2011, Scheinberg and IJgosse 2004).

\begin{abstract}
Box 3 Conflicts in Bulgaria on the frontlines of EU packaging systems In 2003, the Bulgarian national government, in response to the demands of EU accession and harmonisation, implemented a packaging/product tax designed to feed a single, collective, industry-financed physical compliance scheme with $100 \%$ producer responsibility for end of life packaging management (Doychinov and Whiteman 2013, pp. 7, 10-11 et seq.)

The new system was layered on top of an old one, without consultation and also without bothering to deconstruct the mix of habits, economic instruments, and incentive structures that it sought to replace. The EPR designers did not find it necessary to consult with stakeholders about the design of the system, with the result that many of the private companies were driven into resistance, and without their co-operation and knowledge about the recycling value chain, the resulting system floundered. Meanwhile the old system continued to operate, with informal suppliers selling to the formerly state-run buy-back centres. The packaging industry could not show that it was meeting its targets, but through the informal recovery activities, the actual recovery rates were almost certainly higher than the EU-supported targets. With few tonnes flowing through the EUsupported systems, the costs per tonne for formal recovery were unexpectedly high. The industries in the packaging system found themselves in financial difficulties, since they were not getting materials revenues, and could not cover these high per-tonne operating costs.

The Bulgarian system has been much improved and updated, but the early situation represents a useful illustration of a collision between an exclusive EPR system and the informal sector, and shows how failure to involve all stakeholders and seek resolution can create perverse impacts.

Sources: Doychinov and Whiteman (2008), Doychinov (2013), EXPRA (2014), OECD (2016), Soos and Popoviçi (2008), Scheinberg et al. (2010b).
\end{abstract}

In 2008, the Collaborative Working Group on Solid Waste Management in Low- and Middle-income countries held its first meeting in Europe in Cluj-Napoca, Romania. The meeting was hosted by Green Partners, and entitled "Planning in the Real World." The "main lines" of discourse were about the difficulties of planning and implementing EUmandated solid waste system modernisation, in Balkan countries where real, on the ground situations are completely different from Western Europe. The large numbers of informal recyclers in Romania, Bulgaria, Albania, and former Yugoslavian republics are one of the reasons that EU approaches and investments fail to produce the desired results, but until this meeting, the taboos around the informal sector had prevented professionals from engaging with the problems, and elaborating new approaches (Soos and Popoviçi 2008, Whiteman et al. 2009).

Box 4 Aluminium UBC recycling on the streets of Bucharest - the invisible agents Bucharest is the capital of Romania, as well as Romania's largest and most developed city, and the sixth largest city in the European Union (EU). In 2013 the population of about 1.9 million generated roughly 600,000 tonnes of waste or $0.87 \mathrm{~kg} / \mathrm{capita} / \mathrm{day}$, under the responsibility of the city authorities, with collection and disposal services outsourced to private companies. Recyclables reach the value chains either through formal packaging compliance schemes, or through transactions based on informal recovery.

Current research estimates that the informal sector in Bucharest includes at least 1.000 street pickers involved in aluminium used beverage containers (UBC) collection. They collect from apartment and office buildings, open markets, shops, street litterbins, parks and green areas. Of these, $10 \%$ are regarded as "professionals" (working longer hours, collecting consistently more 
materials, and having better equipment, etc.) $80 \%$ are "full-timers", and $10 \%$ are "part timers." The professionals earn minimum wage (200-300 euro per month), while the remaining great majority works to supplement other income or to provide themselves and their families with basic subsistence.

The formal recycling landscape includes approximately 1,000 neighbourhood packaging recycling collection points, operated under the national EPR scheme by the largest EPR organization,

EcoRom. There are also six private sorting stations and approximately 80 private scrap yards buying aluminium UBC. According to an interview with EcoRom, the packaging system recovers $10 \%$ via the formal neighbourhood collection system and $90 \%$ from scrap yards buying $90 \%$ of their materials from street pickers, container pickers, and other private suppliers.

Up until the present, there are no channels of communication between informal suppliers and the EPR system: formal stakeholders see the informal recyclers as thieves of "our materials", but have done little to measure or report the benefits contributed by private informal recyclers, nor to reduce tensions.

Sources: Elaborated by the authors, based on information from Petean and Pop (2015), supplemented by Soos
and Popoviçi (2007), Scheinberg et al. (2010b), Bucharest Municipal Council (2006), Ministry of Environment
and Climate Changes of Romania and The National Environmental Protection Agency (2014), Romanian and Climate Changes of Romania and
Ministry of Environment and Forests (2013).

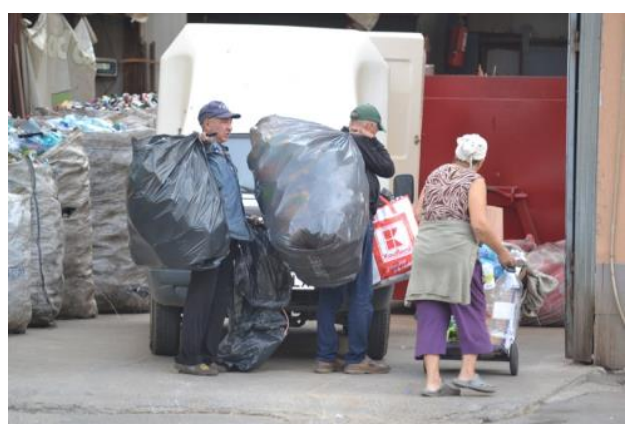

Photo image 1 People queuing up at the recycling centre to valorise their work. 8-9 am is the peak at the scrap yard, since people start collecting early in the morning and also bring the materials collected the previous day. Source: Green Partners

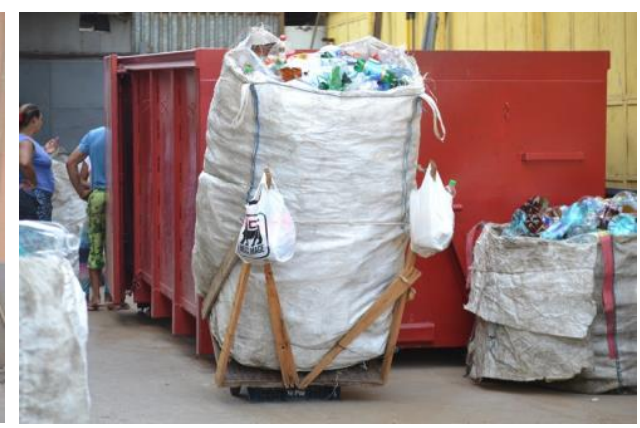

Photo image 2 The quantity collected by a family of three (husband and wife and their daughter) in 6 hours. Mostly plastic, but also $1.5 \mathrm{~kg}$ of aluminium cans. Source: Green Partners

Collisions between informal packaging recyclers and formal EPR packaging schemes in the New EU and pre-accession countries formed the core theme of a regional workshop in Bucharest, Romania, in October 2014, entitled "Challenges to separate collection systems for different waste streams - barriers and opportunities" Representatives of EPR schemes in 10 Balkan and Mediterranean countries including Greece, Turkey, Malta, Tunisia, Romania, Bulgaria, and Macedonia presented their "challenges," which were mainly about the difficulties of competing - largely unsuccessfully -- with established informal sector recycling. Across the wide variety of countries, the following composite picture emerged (EXPRA 2014, OECD 2016, Soos and Popoviçi 2008, Scheinberg et al. 2010b): 
1. Formal EPR packaging recycling systems in the region are having a very difficult time securing materials and documenting their flows to the European Union or meeting agreed-upon targets.

2. In some countries, the EU-conform recycling targets for packaging recovery are actually beneath the recovery rate at the time that the systems were implemented.

3. The level of both overt and covert conflict is high, as formal systems are routinely vandalised. The formal actors blame the informal sector for "stealing" their materials, destroying their infrastructure and undermining revenues and economies of scale.

4. There are some instances of EPR operators entering into dialogue with the informal recyclers, but they are the exception rather than the rule.

\section{Collisions in the Re-use Sector}

Whereas collisions in recycling are often with service chain institutions, those in the re-use sector are more likely to relate to allocation of space and fair treatment of secondhand traders. Issues of urban cleanliness play a role, but there are additional complexities of competition between Roma and non-Roma second-hand operators, and between lower and upper levels of the second-hand value chains.

Box 5 Conflicts with local authorities around the Porta Portese Market in Rome

In 2015 the second-hand and re-use sectors in Rome were documented to include 3,500 itinerant second-hand re-use traders, dozens of second-hand shops, "rigattieri", and 90 consignment shops (Occhio del Riciclone, 2015). More than $70 \%$ of these reuse operators are informal traders, selling their wares in the streets, at fairs, in antique and historical markets, and at pop-up flea markets ("gypsy markets"). Occhio del Riciclone, an Italian political and social development association, estimates in Rome annual re-use sector revenues of 65 million euro, attributable to the informal operations in the sector. Yet despite this economic contribution, the sector enjoys neither recognition nor support from City Hall, there is continuous tension between the city and the operators, and there are numerous instances of small and large-scale conflicts.

Since 2000, organized reuse operators have offered local authorities numerous proposals to formalise and regularise their activities. Act 45 of Rome City Hall (2005) created the legal basis to regularise the supply chains for re-usable waste, but up to the present, none of its recommendations have been achieved. The situation deteriorated further in 2007 when City Hall and its sub-territorial entities introduced an all-out war on informal re-use operators to "clean" the city.

In 2009, 1,000 operators in the historic Porta Portese Marketplace succeeded in defending their interests through demonstrations and blocking traffic. Six "gypsy markets" were shut down one by one. Each closing increased uncontrolled activity and infractions at the margins of the others, which ultimately caused them all to be closed. In 2009 a large number of the displaced Roma operators, forced their way into the Porta Portese Market, creating destabilisation and conflict with the deeply rooted local (non-Rom) operators.

Luckily, the forward-thinking directors of the Association at Porta Portese succeeded in microinterventions that resulted in a dialogue, reducing tensions, creating space for communication, and ultimately solving the conflict. The leaders explained that a "war among the poor" would help no one. Later in 2009, Italian and Roma itinerant operators co-operated in negotiating with City Hall for a transparent and fair system for use of public spaces to sell used goods. This co-operation contributed to the formation of "Rete ONU," the national network of second-hand operators. Rete ONU has succeeded in establishing an official dialogue with the national government and are working actively with the national congress to obtain occupational recognition. One of their key proposals is for the government to establish a second-hand-friendly national extended producer responsibility (EPR) system, and a used durable goods distribution system that is fairer, safer, and 
more reliable than their current strategy of micro-negotiations with a mix of municipal systems. With this in mind, one member of Rete ONU, Mercatini Srl, is working on a measurement instrument for life cycle assessment (LCA) currently being piloted in Turin, that quantifies and valuates the impacts of re-use incentives on the second-hand sector and the host municipalities. This approach would greatly facilitate traceability, which is the core demand made of EU EPR systems for e-waste and other durable goods.

Source: Elaborated by the authors based in part on information from Occhio di Riciclone and Associazione Operatori Porta Portese (2006), Luppi and Sole (2015), Occhio di Riciclone (2008), (2015), Rome City Council (2005), Carabellese et al. (2013), Occhio di Riciclone (2009), Battisti et al. (2013).

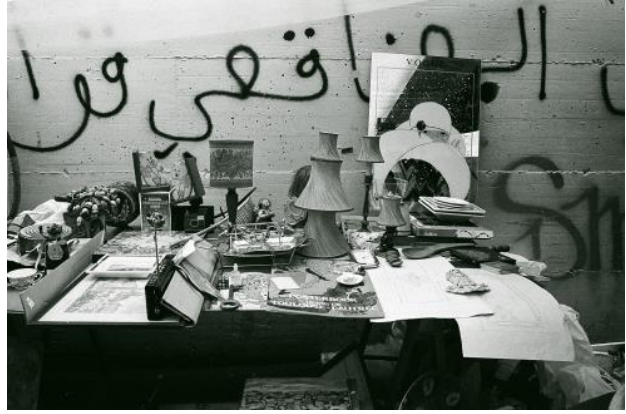

Photo image 3 Porta Portese Flea Market: detail. Photo credit Sebastiano Lauro

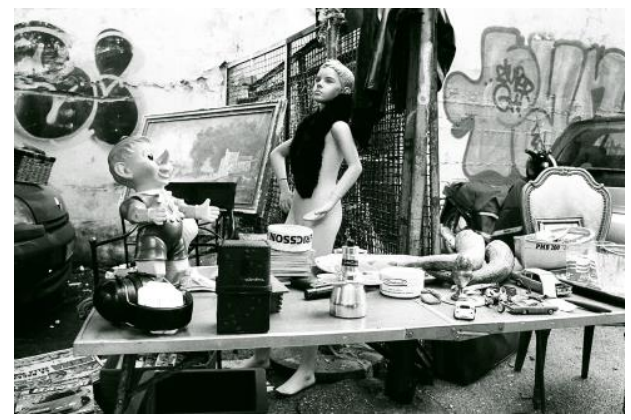

Photo image 4 Porta Portese Flea Market: detail. Photo credit Sebastiano Lauro

\section{Project-based Analysis and Activism}

Earlier work distinguishes between three, four, or sometimes six forms of interventions to bring informal actors in the re-use, recycling, and waste sector into a regularised, stable, and legal relationship with the service and value chains, national social and economic policies, and the activities of local authorities (Velis et al. 2012, ITUC 2014, Soos et al. 2014, Scheinberg and Savain 2015).

Roland Ramusch used his PhD-thesis to propose a variety of approaches for modelling the contribution of the informal sector contribution to recycling. His cumulative approach deals with the elaboration of methodological approaches in order to obtain data on the performance of informal systems directly at the level of informal stakeholders. But in many cases there will be only estimates, no clear data. The concept of triangulation enables a cross-verification of the estimates to quantify informally diverted recyclables. The result is a methodological framework for practitioners to estimate the contribution of informal systems to waste collection and recycling (Ramusch 2015).

Between 2007 and 2008, the IFC Recycling Linkages programme financed the "TARoma" project, which produced recommendations about the need for professionalisation, occupational recognition, and access to bank services credit for informal recyclers, a mix of socio-political and value chain integration. The recommendation about access to credit was taken into the design of the subsequent MATRA "Fair Waste Practices" programme (Ibid., Scheinberg et al. 2012, Whiteman et al. 2009).

USAID, the American international development agency, funded informal recycling integration projects in Macedonia from 2005 to 2013. The goal was to create sustainable livelihoods through small business service chain integration via the municipal waste 
companies, and the project succeeded to create direct employment for at least 5,000 people in waste collection schemes in 24 rural municipalities. Primary waste management schemes were established throughout Macedonia, serviced by informal recyclers, who also gained access to small grants for equipment and working capital for establishment of recycling shops.

Project partners participated in drafting the Law on Packaging and Waste Packaging, thereby taking the first steps toward inclusive EPR. A pilot group of 19 collectors formed the Association of Informal Collectors, with a goal of strengthening the role of the informal waste collectors in EPR systems for packaging waste, as well as promoting their inclusion in the public service chain and the improvement of their economic performance in value chain transactions (Toska et al. 2012, Toska and Lazarov 2007).

In 2006-2008 the International Finance Corporation (IFC) financed capacity development in the recycling sector in Albania, Bosnia-Herzegovina, Macedonia (then FYR Macedonia) and Serbia. The Recycling Linkages Programme had an overall focus on facilitating better business, and trained a number of informal recyclers in the four focus countries, with the aim to improve the functioning (and job-creation potential) of paper, metal, and plastic value chains in post-Socialist and post-war former Yugoslavia (Popovska et al. 2008, IFC 2008, Whiteman et al. 2009, IFC 2010).

Between 2009 and 2011 the Dutch NGO WASTE, Advisers on Urban Environment and Development, together with eight Dutch and Serbian partners, implemented the "Fair Waste Practices" programme, financed by MATRA, a Dutch bilateral development support programme. The focus was strongly on service chain and political integration, with a subset of activities focusing on creating options for technical and operational integration of the informal sector in eight South Serbian municipalities. The multi-stakeholder National Recycling Platform brought many public and private sector stakeholders together and created a safe space for dialogue about informal recycling:

- Serbian waste pickers received national occupational recognition through direct action of YuRom Centar;

- a model for legalising informal recycling through co-operative-based integration was developed and proposed in several cities, but not implemented in the project period;

- some municipal public service companies stated their intention to co-operate with informal recyclers cooperatives via sub-contracts;

- informal sector inclusion in packaging waste recycling was fully endorsed and partially operationalised by two EPR packaging compliance organisations,

- the first European micro-credit scheme to support equipment loans for informal recyclers was implemented by the Serbian micro-credit organisation MicroFins.

The programme closing meeting held in October 2011 in Kopaonik, Serbia, was also the first formal recycling conference in the Balkans where fully half the participation was by informal recyclers (DTI 2012), supported by the YuRom Centar, one of the few European organisations with a focus on informal integration and legalisation, whose website describes their mission as follows:

"Providing innovative employment solutions for Roma people excluded from the formal labour market through a sustainable waste management initiative, and assisting these persons in obtaining identity cards and their full enjoyment of citizenship rights, while also addressing environmental protection issues related to waste." (Balić 2014, Conseil de l'Europe 2013). 
One of the first events specifically to focus on formalisation of entrepreneurs in the European informal re-use (and recycling) sectors occurred as a closing event of the TransWaste project in September 2012. Many of the sources in this review were developed for that conference as presentations, and later published.

The TransWaste project produced a socio-economic integration approach for a number of Hungarian, Slovakian, and Polish re-use enterprises. Three distinct strategies were identified, which are coherent with the global ideas about integration, as shown in Table 4.

Table 4 Three types of integration for the European re-use sector in the global context

\begin{tabular}{|c|c|c|}
\hline $\begin{array}{l}\text { Integration } \\
\text { approach }\end{array}$ & Description & Corresponding global approach \\
\hline $\begin{array}{l}\text { WISE (Work } \\
\text { Integration Social } \\
\text { Enterprises): }\end{array}$ & $\begin{array}{l}\text { Integration of the informal sector } \\
\text { into the establishment of re-use } \\
\text { and repair networks in } \\
\text { cooperation with WISE }\end{array}$ & $\begin{array}{l}\text { Social enterprises } \\
\text { (Iskandar and Shaker 2007, Ishengoma } \\
\text { 2006, Oyake-Ombis 2012, Scheinberg et } \\
\text { al. 2010a) }\end{array}$ \\
\hline $\begin{array}{l}\text { Used product } \\
\text { corner: }\end{array}$ & $\begin{array}{l}\text { Implementation of a used product } \\
\text { corner in waste collection centres }\end{array}$ & $\begin{array}{l}\text { Legal access to materials via newly created } \\
\text { legal channels; North American "take it or } \\
\text { leave it" at rural transfer stations } \\
\text { (Chikarmane et al. } 2008 \text {, Scheinberg } 2011 \text {, } \\
\text { Scheinberg and Savain 2015) }\end{array}$ \\
\hline $\begin{array}{l}\text { Collector } \\
\text { association: }\end{array}$ & $\begin{array}{l}\text { Forming of an used item collector } \\
\& \text { retailer association in the home } \\
\text { countries of the informal waste } \\
\text { collectors }\end{array}$ & $\begin{array}{l}\text { Social integration and the solidarity } \\
\text { economy } \\
\text { (Soos } \text { et al. } 2014 \text {, Rutkowski and } \\
\text { Rutkowski } 2015 \text {, Gutberlet } 2008 \text {, Velis } \text { et } \\
\text { al. } 2012 \text {, Godfrey 2016) }\end{array}$ \\
\hline
\end{tabular}

Under leadership of a patriarch of a second-hand goods trading family, Mr. Janos Kozák, the TransWaste project supported the formation of ISHS (International Second Hand Service), a traders' association. The project pioneered a legal export procedure for traders, based on a listed load manifest, that allowed traders to show that their vans contained legally procured items. The mayor of the city of Devecser, the Western Hungarian hub of the trans-boundary second-hand trade in Europe, supported the organization and provided an unused military complex for the traders to sort and store their items. Unfortunately the gains made by ISHS were not anchored in new laws or regulations. At the Antwerp meeting in 2015, Mr. Kozak reported that the new mayor of Devecser withdrew public support for ISHS, and the situation deteriorated after the close of the project (Schmied et al. 2011, Kozák 2012).

\section{Constructive Approaches to Co-operation in Europe.}

Occhio del Riciclone (OdR) coordinated and incubated the development of Rete ONU, the largest association in Europe of informal workers and enterprises in the re-use and recycling sector, with 1100 members and many more affiliates. More than $70 \%$ of re-use enterprises in Rome are informal, and are jointly responsible for a total revenue estimated at Euro 65 million per year. They are working with one of their members, Mercatini SRL, on a methodology based on life cycle assessments (LCAs), to document the interactions between incentives for re-use and the system-level benefits of optimising the life cycle of 
products. In the TransWaste Project, LCAs were also used to model the environmental benefits of the trade in second-hand white goods (kitchen appliances). Outside of Europe, there is an increasing literature on the contribution of informal recyclers to reducing $\mathrm{CO}_{2}$ emissions (Chaturvedi 2009, King and Gutberlet 2013, Ramusch et al. 2015, Occhio del Riciclone 2008, Occhio del Riciclone 2015, Soos and Popoviçi 2007, Soos and Popoviçi 2008, Scheinberg et al. 2010b, Sim et al. 2013, ILO 2013).

Session 2 of the final conference of the project "TransWaste" was dedicated to the topic of organising waste pickers in Europe and included representatives from Hungary, Romania, Bulgaria, Serbia, Macedonia and Italy. After the main meeting there was a second "private" session where the European re-use operators and informal recyclers and their allies could exchange with each other. It was a first step of bringing informal recyclers and advocating institutions together at European level in order to discuss local peculiarities and problems related to informal activities (Linzner 2012, Linzner and Lange 2013, Ramusch 2015, Ramusch and Obersteiner 2012, Ramusch et al. 2015, Schmied et al. 2011, Obersteiner et al. 2012, Kozák 2012).

The ISWA 2015 World Congress in Antwerp, Belgium approved a related side event, a first meeting for European recycling and re-use operators and their advocates and allies, to share experiences, challenges and strategies.

Mr. Alphan Eröztürk of the Turkish Environmental Protection and Packaging Waste Recovery Trust (CEVKO) and Chairman of the Board of EXPRA, the Extended Producer Responsibility Alliance, participated in the meeting. His presentation began with a quick Republic of Turkey recycling status report: 77.695.904 people, 31.762 .085 tonnes of waste per year, $409 \mathrm{~kg}$ per person, a single digit recycling rate and an estimated 71,000 street pickers. Recyclables from households and street set-outs are mostly collected by the informal sector (Eröztürk 2015).

Up until 1991 recyclables in Turkey were collected by waste pickers or simply left in the waste going to a local dumpsite. In 1991 the separate collection of wastes became a legal obligation and most municipalities stopped allowing dumpsite sorting. In the early 2000s, as the Turkish government began to regulate waste management, picker legality became an issue. In 2005 packaging producers became legally responsible for the capture, safe management and recycling of all packaging. Clash! Most of the knowledge and activity were in the informal sector, but the investment funds were all on the formal side.

In response, the EXPRA Street Collector Initiative, was designed to study these issues and learn more about the informal sector - demographics, infrastructure needs, preferences and best practices and then to develop win-win solutions especially in terms of social integration - fair wages, housing, social rights, legality and stability. CEVKO, working in cooperation with NGOs and municipalities has organized 3 meetings with Turkish street collectors (Eröztürk 2015).

Informal re-use operators and recyclers at the Antwerp meeting were amazed that a producer's organisation would actively seek ways to co-operate. What Mr. Eröztürk described sounded like a fairy tale; they had questions about self-employment, markets, price protections and exporting. Some stated that it should not be required to have a permit to accept recyclables that are donated to the informal sector by the households. There was approval but also broad concern that many pickers are not eligible for formalization and that this approach would take away access to materials and markets, and they would lose livelihoods and their only way to support their families. 


\section{SUMMARY, DISCUSSION, AND CONCLUSIONS}

\section{Summary of the Review}

The literature, a mix of scholarship, conference papers, initiatives and projects, provides a surprisingly rich mix of information and experience on the European informal re-use and recycling sector. The core of the review is 78 sources, which have a clear and/or exclusive focus on informal re-use or recycling in Europe. In this case Europe is defined as including European Union member states, countries in the process of acceding to the EU or in the pipeline to start negotiations, and countries which are direct or regional neighbours and in some sense fall under the EU sphere of influence. (Gutberlet 2008, Rutkowski and Rutkowski 2015, Schmied et al. 2012).

These 78 sources have been classified into four types of work:

1. Scholarly article, scholarly, student, or action research, conference, project report,

2. Social or labour advocacy and/or organising,

3. Policy documents, laws, government, donor consultant reports, plans, and

4. Direct information provided by individuals or organisations working on informal recycling and re-use in Europe, or from their websites, including those who prepared the text boxes in the article.

The types of sources were then classified by the status of the country they refer to:

1. EU member, Italy, Belgium, etc.

2. Pre-accession and/or accession pipeline country, for example Turkey or Serbia

3. EU neighbour and "sphere of influence" country, such as Albania, Morocco, Tunisia or Kirgizstan

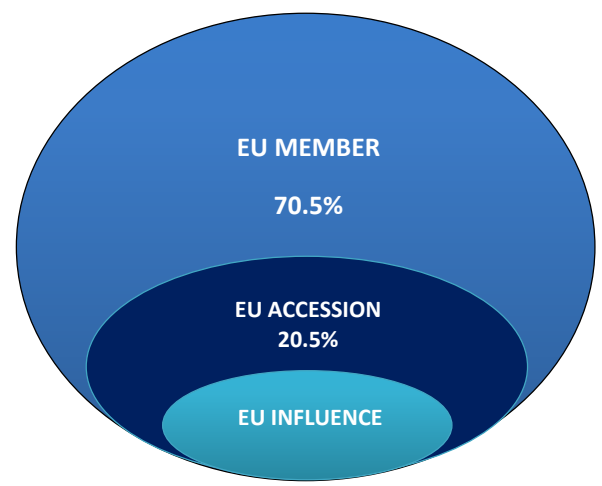

Fig. 1 Review of Literature by Type of Country

Perhaps the most interesting insight is that $70 \%$ of the sources focused on the informal sector in countries that are currently members of the European Union, as opposed to countries seeking to join the EU. Informal recyclers and re-use operators exist in Europe, and are a part of the landscape of recycling and re-use within the European Union, and there is therefore little to be gained by denying their existence. 
We refer to the third classification as the "locus" of the research or the initiative. By this we mean the institutional site of research, project, or intervention:

a) The service chains

b) Social and labour ministries, occupational recognition, advocacy, union organising

c) EPR and PS (Product Stewardship) systems

d) The value chains, including both recycling and re-use value chains and end-use markets

e) Projects or interventions that are associated with civil society, for example, NGOs, social entrepreneurship, faith-based charities, community development, or similar.

Table 5 analyses the distribution of articles across these five focus areas of conflict and integration.

Table 5 Locus of conflict and/or integration

\begin{tabular}{|c|c|c|}
\hline The service chains & 40 & $51.3 \%$ \\
\hline Social and labour ministries, occupational recognition, advocacy, union organising & 8 & $10.3 \%$ \\
\hline EPR and PS (Product Stewardship) systems & 7 & $9.0 \%$ \\
\hline $\begin{array}{l}\text { The value chains, including both recycling and re-use value chains and end-use } \\
\text { markets }\end{array}$ & 21 & $26.9 \%$ \\
\hline $\begin{array}{l}\text { Projects or interventions that are associated with civil society, for example, NGOs, } \\
\text { social entrepreneurship, faith-based charities, community development, or similar. }\end{array}$ & 2 & $2.6 \%$ \\
\hline
\end{tabular}

$$
\text { Source: elaborated by the authors. }
$$

Contrary to the initial assumptions of the authors of this paper, more than half of the sources were published scholarly works. This suggests that while the topic is still quite new, there is robust activity to research issues and establish baselines. Scholarship is leading advocacy by quite a lot, and there is also more scholarship than policy formulation. This also suggests that the researchers could become a resource to the policymakers.

There is another important finding coming from this information. The fact that only $16 \%$ of literature sources comes from advocacy papers and direct information tells us that the work of the informals, as well as initiatives to reduce conflict or stimulate cooperation, might not yet be adequately supported by civil society organizations able to document what happens on the ground. These organizations are either too engaged in implementation to document, or lack resources or a culture of reporting that would result in them documenting the process and results. 


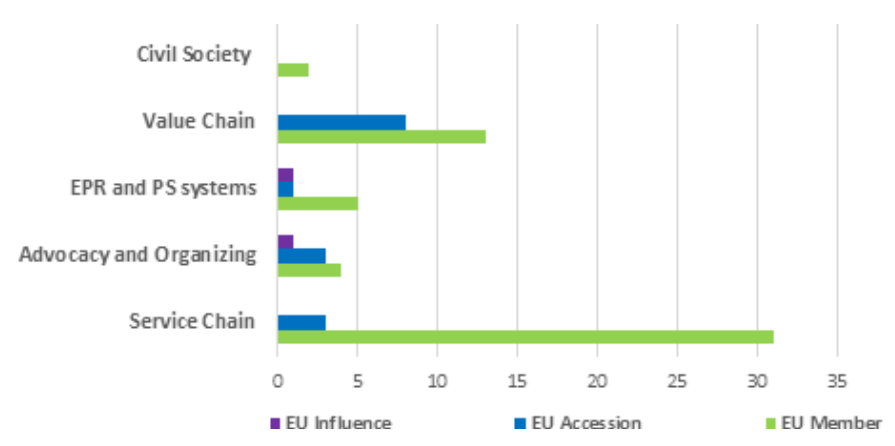

Fig. 3 Locus of Conflict and/or Integration by Type of Country

Source: elaborated by the authors.

This figure highlights the sectors engaged in creating integration opportunities and therefore is an indicator of where conflict is likely to be found. Sources with their main focus on EU Accession countries, show the most robust focus on the value chain. Lack of civil society sources suggests that although there may be initiatives run by civil society, there is no culture of documentation - or too many language barriers - to have produced sources that would come to the attention of a (primarily) English-language review.

Sources on EU Influence countries show examples of EPR and PS systems and advocacy and organizing, while there are no documents indicating issues with either service or value chains, nor civil society.

By far the most sources focus on EU member states with emphasis on conflicts, cooperation and co-production in the service and value chains. Demonstrated interest in advocacy, civil society and EPR and PS systems are much lower. This suggests that in these countries, research and practice are more directed towards improving practical results. The lack of civil society activity may suggest that there is little activity on culture change or in shifting stakeholders' opinions in relation to informal activity.

\section{Moving towards a census on informal recyclers and re-use operators in Europe}

The review did not find evidence of a source of reliable and verifiable census numbers for European recyclers, but it does provide some indicative numbers and descriptive factors. To start, most waste pickers in the EU belong to one or more of three vulnerable groups:

1. Persons of Roma ethnicity, who have very low educational levels and are the targets - especially in Italy - of a range of social exclusion measures, and

2. Internal and cross-border migrants and refugees without legal status or lacking formal identity papers, and

3. Young persons, the elderly, women heads of household, homeless persons and others who are excluded from the labour market.

An accumulation of research results and estimates by practitioners suggests that the numbers are large. Estimates of numbers of informal re-users and recyclers in Europe, from the review, suggest that there might be as many as one million active:

- 80,000 second-hand and re-use operators in Italy

- 71,000 in Turkey

- up to 50,000 in Serbia 
- 20,000 in Greece

- 20,000 in Paris

- 5,000 in the Western Hungarian city of Devecser

- 5,000 in Skopje, Macedonia

(Ramusch et al. 2015, Schmied et al. 2011, DTI 2013, Scheinberg and Nesić 2014, Luppi and Sole 2015, Simpson-Hébert et al. 2005, Kozák 2012, Eröztürk 2015, Springloop 2016).

European waste pickers have many of the same vulnerabilities as waste pickers elsewhere, but they have also some unique challenges. Some significant similarities and differences between European informal recycling and similar situations in middle-income countries in Asia, Africa, and Latin America emerge.

Table 6 Summary of Differences Between European and Non-European Informality in the Re-use and Recycling Sectors

\begin{tabular}{|c|c|c|}
\hline Parameter & Outside Europe & Europe \\
\hline $\begin{array}{l}\text { Existence and } \\
\text { status }\end{array}$ & $\begin{array}{l}\text { Waste picking occurs widely in large cities } \\
\text { and where there is growing welfare; } \\
\text { numbers in Africa are small, in emerging } \\
\text { economies in Asia and Latin America very } \\
\text { large }\end{array}$ & $\begin{array}{l}\text { European informal recycling well } \\
\text { established, and the numbers in } \\
\text { South-east Europe are moderate to } \\
\text { large }\end{array}$ \\
\hline Social identifiers & $\begin{array}{l}\text { Internal (rural-urban) migrants, } \\
\text { unemployed and homeless persons, } \\
\text { women heads of household, ethnic and } \\
\text { religious minorities. }\end{array}$ & $\begin{array}{l}\text { Young men of Roma ethnicity } \\
\text { dominate among "full-time" waste } \\
\text { pickers }\end{array}$ \\
\hline $\begin{array}{l}\text { Full-time/part } \\
\text { time }\end{array}$ & $\begin{array}{l}\text { Colombian researchers divide waste } \\
\text { pickers into "authorised," "unaffiliated", } \\
\text { and "street persons." }\end{array}$ & $\begin{array}{l}\text { Many European informal recyclers } \\
\text { see waste picking as a part-time or } \\
\text { seasonal alternative to other forms } \\
\text { of work. }\end{array}$ \\
\hline $\begin{array}{l}\text { Occupational } \\
\text { recognition }\end{array}$ & $\begin{array}{l}\text { Occupational recognition for "full-time" } \\
\text { waste pickers is growing. }\end{array}$ & $\begin{array}{l}\text { Occupational recognition is } \\
\text { extremely rare and outside of } \\
\text { European statistics. }\end{array}$ \\
\hline $\begin{array}{l}\text { Informality in } \\
\text { the service chain }\end{array}$ & $\begin{array}{l}\text { informal service provision (micro- } \\
\text { privatisation of waste collection, is } \\
\text { common in the service chain in sub- } \\
\text { Saharan Africa and growing in Asia }\end{array}$ & $\begin{array}{l}\text { Service chain informality is limited } \\
\text { to under-served rural areas, or to } \\
\text { "side" jobs such as cleaning out } \\
\text { attics or removing bulky waste }\end{array}$ \\
\hline $\begin{array}{l}\text { Barriers to } \\
\text { legalisation }\end{array}$ & $\begin{array}{l}\text { Experiences in Asia and Latin America } \\
\text { have produced progress in legalising and } \\
\text { integrating informal recyclers in the } \\
\text { framework of municipal waste } \\
\text { management (and the service chain) }\end{array}$ & $\begin{array}{l}\text { There are a few fragile examples of } \\
\text { legalisation of re-use operators, and } \\
\text { some intentions to legalise and } \\
\text { integrate recyclers of packaging, but } \\
\text { the taboos and resistance are very } \\
\text { strong }\end{array}$ \\
\hline $\begin{array}{l}\text { Potentials for } \\
\text { integration }\end{array}$ & $\begin{array}{l}\text { Integration in the service chain as official } \\
\text { recyclers has a good basis and potential to } \\
\text { expand; the introduction of EPR systems } \\
\text { for packaging in countries like South } \\
\text { Africa and Indonesia appears to offer } \\
\text { interesting new opportunities }\end{array}$ & $\begin{array}{l}\text { Integration in the service chain } \\
\text { appears to be extremely difficult; } \\
\text { better potential exists in relation to } \\
\text { EPR systems new EU directives on } \\
\text { waste prevention and re-use }\end{array}$ \\
\hline
\end{tabular}

Source: elaborated by the authors based on ILO (2004), Vaccari et al. (2013), Mendonça (2015), Sim et al. (2013), Scheinberg and Anschütz (2006), ITUC (2014), Scheinberg (2011), Dias (2006), Scheinberg and Nesic (2014), Schmied et al. (2011), Ramusch and Obersteiner (2012), Linzner et al. (2011), Gutberlet et al.(2016) . 


\section{SWOT of European Waste Pickers in the Recycling and Re-use Sectors}

European waste picking in the recycling and re-use sectors has both challenges and benefits.

European waste pickers share with their counterparts in other emerging economies, some core features and attributes. A brief SWOT analysis illustrates this:

Table 7 SWOT Analysis of European Waste Pickers in Recycling and Re-use Sectors

\begin{tabular}{lc}
\hline STRENGTHS (internal characteristics) & W \\
\hline - & Responsible for most of the recycling outside \\
& of the "old EU, even where EPR systems exist
\end{tabular}

WEAKNESSES (internal characteristics)

Activities contribute to cities achieving re-use

Originate from socially disadvantaged groups, and recycling goals

- Manage substantial volumes of materials, keeping them out of landfills

- Legally support themselves and their families

- Deep recycling knowledge and strong commercial connections to the value chains

- Actively trade in second-hand, flea market, and antique sector

- Generally interested in improving their situations and legalising their work

- Have ideas of what they need for legalisation and improvement

OPPORTUNITIES (external influences)

- New EU commitments to the hierarchy demand higher performance in the re-use and recycling sectors

- EU circular economy package is likely to increase recyclability of many products and packages

- Circular economy reporting systems creates an opportunity to register informal recycling transactions and material flow

- New registration systems can form the basis for meeting new demands for tracking and traceability of packaging and EPR systems, and be a channel for transfer of funds from producers to informal actors.

- Interchange of information between European countries and emerging economies creates a growing understanding of the sector and sets the stage for occupational recognition at the European level, and creates some momentum for engagement

Source: elaborated by the authors based on Simpson-Hébert et al. (2005), Samson (2009), Scheinberg et al. (2010b), Popovska et al. (2008), IFC (2008), Wilson et al. (2010), Scheinberg and Mol (2010), Scheinberg and Nesić (2014), Soos and Popoviçi (2007), Soos and Popoviçi (2008), Scheinberg et al. (2010a), Gutberlet (2008), Rutkowski and Rutkowski (2015), Schmied et al. (2011). skills, unstable living situations, and little experience with accessing public facilities or claiming their rights

- Activities exist based on disappearing opportunities, including legal access to materials and tolerance for their activities

- Little interest in or experience in organising themselves, or creating representation

- Lack experience navigating necessities of legalization such as registering enterprises and working in permitted areas.

- A substantial number lack legal identity

THREATS (external influences)

- There is entrenched mutual distrust between formal institutions and informal re-use operators and recyclers.

- The European waste management service sector is under increasing pressure to perform, and this translates to an imperative to prevent informal valorisation on landfills and streets. There is increasing economic pressure on the solid waste sector and formal public and private stakeholders are not so willing to share responsibilities and resources

- Local authorities do not necessarily want to legalise illegal persons because they will gain access to education and medical facilities which are already under-financed.

- European local authorities may prefer to develop re-use and recycling and circular economy institutions through civil society and the formal private sector 


\section{New Insights Coming from the Review}

Experiences with informal integration and formalisation in Europe have mostly been project-based and formulated in response to financing opportunities, and without (much) consultation with the informal actors themselves. When considered together, and in contrast to recycling experience in civil society, this body of work advances the knowledge base by clearly disqualifying project-based integration experiments as unproductive and unsustainable.

Service- and value chain integration projects in Hungary, Macedonia, and Serbia made substantial gains during the project period, and opened up the spaces for dialogue. Despite positive results, none of these projects succeeded to make structural change, and gains made in these initiatives appear to have faded out after the closing of the projects. This may be due to the fact that European waste pickers, in contrast to their counterparts in Asia or Latin America, are more likely to identify themselves as individual or micro entrepreneurs, and are less interested in solidarity and more in pure economic performance

The post-project critique of YuRom Centar's Osman Balić about the Serbian Fair Waste Practices project is more generally applicable to European informal integration and organising projects: they do not succeed to make informal recyclers better off over the long term, and they often create expectations and false hopes which are not realised. Even ISHS, the successful TransWaste association of re-use operators in Devecser, Hungary, did not survive the change of mayors of that city. In contrast, Rete ONU, the Italian re-use association, appears more robust and long-lived, perhaps because it was created without project support, by and for re-use operators, and it serves their daily business needs (DTI 2012).

\section{Recommendations for Constructive Approaches Drawn from the Review}

The conclusions and recommendations of the recent aluminium UBC study in Bucharest (detailed in Box 4) propose some leading candidates for a constructive approach to working with the issues of informal re-use and recycling in the European Union, accession countries, and in the EU sphere of influence. That study, designed to support packaging producers in developing a structural approach to materials capture, states that:

"A first step would be for city and national authorities to initiate a working group and conduct an assessment on the necessary conditions needed to allow natural persons to become legal recycling agents potentially in association with some form of price support from the producers' organizations and the recently introduced landfill tax. There is some merit to considering a preliminary award scheme based on documented and validated recovery performance. Later steps could include promoting associations or co-operatives, and integrating informal recyclers into new separate collection schemes along the lines advocated in Wilson et al. (2006)." (Petean and Pop 2015).

This quote nicely anticipates the main insights from the review, in identifying three pillars - legalisation, occupational and enterprise recognition, and systematic integration of informal re-use and recycling into formal EU recycling and circular economy processes, that are essential to developing a pan-European response to informal valorisation. A fourth pillar, documentation and benchmarking, is logically prior to the others, and is needed a basis for planning, evaluation, and fine-tuning of the activities and initiatives. The authors thus conclude this review with the following recommendations for pragmatic approaches to foment more co-operation and less conflict. 


\section{Overarching Recommendation: Bring Informal Integration \\ into the Circular Economy Package in a Structural Way}

The overarching recommendation is to locate actions in relation to informal re-use and recycling within the framework of the European Circular Economy Package (European Commission 2016b). This planned package of legal, regulatory, institutional and technical reforms proposes far-reaching changes to how materials are managed in Europe, and appears to provide a productive institutional home for regularising recycling and re-use activities. Structural change is preferred to project-based integration, since projects have so far generally failed to produce long-term change.

Within this, the four pillars of a constructive approach can be elaborated as follows.

\section{Pillar 1: Documentation, Benchmarking and Statistics}

The first recommendation is to assign Eurostat to work within the framework of the EU Circular Economy Package to increase and improve documentation of informal recycling and re-use in all EU, accession, and EU sphere of influence countries, with a focus on:

a) collection and validation of socio-economic numbers: census, ethnicity, sex, age, location, numbers of people living from informal recycling and re-use, vulnerabilities, and the like;

b) technical and economic performance and impact numbers: numbers of tonnes diverted from disposal through informal valorisation activities, and associated with modelling of negative and positive impacts. This should be integrated with traceability approaches for EPR schemes and possibly also linked to a system of incentives or price supports.

c) occupational and professional characteristics: occupations by country and city and rural/urban distribution; institutions and enterprises that have a link with the informal sector;

d) revisiting analysis of aspects of the European waste system where there are large reported "losses" of hazardous wastes or e-waste to examine the role of informal activity and whether legalisation and integration could improve the effectiveness of tracking and traceability in Europe, and

e) creating specific procedures for reporting, benchmarking and legalisation at the level of EU directives in the framework of the Circular Economy Package.

\section{Pillar 2: Legalisation Options and Opportunities}

Informal integration in Europe will have to have a strong focus on legalisation, and this makes it different from integration experience in Colombia, Egypt, or India. Legalisation initiatives (not projects) should be based on exploring and "stretching" the institutional spaces for experimentation with legalisation and integration in countries like Serbia, Turkey, and Macedonia where formal institutions in the service chain and/or in EPR systems have shown some positive interest in the issue Eröztürk 2015, Toska et al. 2012). Some steps towards legalisation could include:

a) inviting informal recyclers and re-use operators to co-operate with public institutions in identifying common goals, barriers, and approaches to legalisation;

b) discovering and creating spaces for legalisation and possibilities for co-operation; 
c) creating a vocabulary of legalisation and integration strategies;

d) identifying sources of financing and technical support for project-based integration and legalisation where it is latent, and

e) supporting early adopter (non-project) legalisation and integration initiatives that lead to sustainable changes at medium-scale.

\section{Pillar 3: Occupational and Enterprise Recognition as Circular Economy Agents}

Up to now it appears that Serbia might be the only EU country with occupational recognition of "collectors of secondary raw materials". While the precise mechanism to achieve this is unclear, it appears that the Circular Economy Package could also provide an umbrella for the development of occupational categories in re-use and recycling. Since the International Labor Organisation is already involved with this, perhaps a co-operation between ILO and Eurostat could form the basis to standardise the approach of the labour ministries of individual member and pre-accession states.

\section{Pillar 4: An Inclusive European Circular Economy: Structural and Systematic Integration of Informal Re-use Operators and Recyclers}

The authors of this paper believe that the long-term vision must include a commitment - within EU legal and regulatory frameworks - to ensure that the waste directives and the Circular Economy Package have a component of economic and social inclusivity. That would mean that re-use operators and recyclers operating in the informal economy in Europe have access to a reliable, fair, and long-term process to legalise their status, stabilise their conditions and position, and participate in the circular economy as economic agents. Getting to this will not be easy, and it will perhaps take quite a long time, but it is important, both to the environment and to the economy of a wellfunctioning Europe.

\section{REFERENCES}

Abarca, L, Bogantes, B, \& Hernandez, E, (2002) Estudio social y económico de los recuperadores de botadero en Río Azul, Curridabat. Tecnología en Marcha 15(4). pp 49-59.

$\mathrm{ACR}+$ (Association of Cities and Regions for Recycling and Sustainable Resource Management) (2009) Municipal Waste in Europe, Towards a European Recycling Sociaty. Paris, France, Victoires Éditions

Ahmed, R, van de Klundert A \& Lardinois I (1996) Rubber Waste, Options for Small-scale Recovery. Urban Waste Expertise Programme (UWEP) Publication 3, Leiden, the Netherlands, Tool Books.

Balić, O (2014) General framework of Employment and Social Policies Reform Programme for European Union candidate countries -- Roma Support Measures - Serbia. Statement of YuRom Centar in support of the General Framework. Nis, Serbia, Yurom Centar. Available at: http://www.yuromcentar.org.rs/en/news/64general-framework-of-employment-and-social-policies-reform-programme-for-european-union-candidatecountries (accessed April 12 2016).

Battisti M, Fabbri G, Luppi P, Merciai S, Pannone A (2013) Analysis of the environmental impact of the reuse of assets managed by a secondhand commercial enterprise in Italy. Verona, Italy. Available at: http://www.occhiodelriciclone. com/attachments/article/1009/LCA\%20PAPER\%20EN.pdf (accessed March 15 2016).

Belghazi, S (2008) Analyse des Impacts Sociaux et Sur la Pauvreté de la Réforme du Secteur des Déchets Solides Ménagers Au Maroc, Coopération Belge, PNUD, Banque Mondiale, Secrétariat d'Etat Chargé de l'Eau et de l'Environnement. Available at: http://web.worldbank.org/archive/ website01016/WEB/IMAGES/ PSIA_PND.PDF (accessed April 4 2016) 
Bucharest Municipal Council (2006) Strategia de dezvoltare şi funcţionare a serviciului public de salubrizare în municipiul Bucureşti. Bucharest City Ordinances, available at: http://www4.pmb.ro/wwwt/institutii/CGMB/ sedinte/ordinea_de_zi/db/18_20100510. pdf (accessed April 18, 2016).

Carabellese M, (2013) Frammenti di territorialitá Rom. Il caso dei raccoglitori informali di rifiuti a Roma , Rome, Italy. Bollettino della Societá Geografica Italiana, series XIII, Vol VI, pp. 279-292.

CEMPRE Colombia (2014) Website of CEMPRE, the Compromiso EMpresarial Para el REciclaje, a membership organization of global producers in Colombia. http://www.cempre.org.co (accessed January 212016 )

Chaturvedi, B (2009) Cooling Agents, An Analysis of Greenhouse Gas Mitigation by the Informal Recycling Sector in India. From Chintan-Environmental Publications, New Delhi, India (2016). Available at: http://www.chintanindia.org/publications_research_reports.htm (accessed January 27 2016)

Chen, M A (2012) The Informal Economy: Definitions, Theories and Policies. WIEGO Working Paper No 1. From www.wiego.org/publications/informal-economy-definitions-theories-and-policies (accessed December 162015 )

Chikarmane, P \& Narayan L (2009) Rising from the Waste - Organising Wastepickers in India, Thailand and the Philippines. Bangkok, Thailand. Committee on Asian Women (CAW) Available from: http://www.swachcoop.com/ pdf/CAWAsianWastepickersPCLN.pdf (accessed on March 31 2016)

Chikarmane, P Narayan L \& Chaturvedi B (2008) Recycling Livelihoods-Integration of the Informal Recycling Sector in Solid Waste Management in India. GTZ (now GIZ) sector project "Promotion of Concepts for Pro-Poor and Environmentally Friendly Closed-Loop Approaches in Solid Waste Management” Eschborn, Germany. Deutsche Gesellschaft für internationale Zusammenarbeit (GIZ). Available at:http://swachcoop.com/pdf/Recycling Livelihoods_2008.pdf (accessed on March 31 2016)

Chikarmane, P, Deshpande M \& Narayan L (2001) ILO-SNDT Study Of Scrap Collectors, Scrap Traders and Recycling Enterprises. Geneva, Switzerland, International Labor Organization. Available from http://www.swachcoop.com/pdf/ILO\%20Study.pdf (accessed April 2 2016).

Cohen, P, IJgosse J, \& Sturzenegger G (2013) Preparing Informal Recycler Inclusion Plans: An Operational Guide. Washington DC, USA, World Bank and Inter-American Development Bank.

Conseil De L'Europe (2013) Good Practice 26 Serbia - Providing Innovative Employment Solutions For Roma: Swift Sustainable Waste Management Initiative. Website of the Council of Europe, available at: http://goodpracticeroma. ppa.coe.int/en/pdf/145 (accessed April 9 2016).

Dias, S M (2006) Waste and Citizenship Forums - Achievements and Limitations. Paper \#11. CWG-WASH Workshop, Kolkata, India http://wiego.org/specialists/sonia-dias

Doychinov, N (2008) The Bulgarian EkoPak Experience. Presentation given at the IFC Recycling Linkages Summit, Belgrade, November 2008. Washington DC USA, International Finance Corpoation (IFC www.ifc.org/pepse

Doychinov, N \& Whiteman A D (2013) Operator Models. Respecting Diversity Concepts for Sustainable Waste Management, Economic Instruments in Solid Waste Management Case Study Bulgaria. Deutsche Gesellschaft für Internationale Zusammenarbeit (GIZ) Eschborn. Available from http://rwagroup.net/projects/ (downloaded January 2016), and/or from www.giz.de/giz2013-en-economic-instruments-bulgaria (accessed June 192015 ).

DTI (Democratic Transitions Initiative) (2013) MIREA Proposal to the Europe Aid programme of the European Union: Mainstreaming Informal Recycling in Europe and Africa. Not available from internet, please contact second author of this paper for access.

DTI (Democratic Transitions Initiative) (2012) Proceedings and Papers from Pandora's Container, the Closing Meeting of Fair Waste Practices. In the final report of Fair Waste Practices. Democratic Transitions Initiative Belgrade, Serbia. Not available from internet, please contact second author of this paper for access.

Eröztürk, A (2015) Street Collectors - The Facts and Solution Alternatives. Presentation given at the Antwerp Meeting of European Waste Pickers, September 7, 2015, Antwerp, Belgium. Ankara, Turkey,, Environmental Protection and Packaging Waste Recovery and Recycling Trust (CEVKO). Presentation available from authors of this paper.

European Commission (2008). Waste framework directive. Available from http://ec.europa.eu/environment/waste/ framework/ (accessed April 5 2016).

European Commission (2015) European Waste Legislation. Website of European Environment, updated 30 March 2016. http://ec.europa.eu/environment/waste/legislation/a.htm (accessed April 5 2016).

European Commission (2016a) Review of Waste Policy and Legislation. Update to the website of the European Commission 30 March 2016. Available at http://ec.europa.eu/environment/waste/target_review.htm (Accessed April 16 2016).

European Commission (2016b). Circular Economy Strategy Closing the loop - An EU action plan for the Circular Economy. Website of European Environment, updated 22 April 2016. http://ec.europa.eu/environment/circulareconomy/index_en.htm (Accessed May 20, 2016).

European Environmental Agency (EEA) (2011) Earnings, Jobs, and Innovation: The Role of Recycling in a Green Economy. Copenhagen, Denmark. EEA.

European Environmental Agency (EEA) (2009). Diverting waste from landfill Effectiveness of waste- management policies in the European Union. EEA Evaluation report. Available at: http://www.google.nl/url?sa=t\&rct=j\&q= 
$\&$ esrc $=$ s\&source=web\&cd=2\&ved=0ahUKEwiPztSNtJrMAhXjO5oKHYqNBOUQFggmMAE\&url=http $\% 3 \mathrm{~A} \% 2$ F\%2Fwww.eea.europa.eu\%2Fpublications\%2Fdiverting-waste-from-landfill-effectiveness-of-waste-managementpolicies-in-the-european-union\%2Fdownload\&usg=AFQjCNGv_PQpf760B1pP1up80B8PGxuxmQ (accessed April 16 2016)

Eurostat (The statistical office of the European Union) (2015) Statistics Explained: Building the System of National Accounts - informal sector. Available at: c.europa.eu/eurostat/statistics-explained/index.php/ Building_the_System _of_National_Accounts_-_informal_sector\#Place_of_the_informal_sector_in_the_economy (accessed April 18 2016).

EXPRA, the EXtended Producer Responsibility Alliance (2014). Summary report of the ISWA / RDN / EXPRA Workshop: Challenges to separate collection systems for different waste streams - barriers and opportunities. October 2014, Bucharest, Romania. Available at: http://www.expra.eu/uploads/downloads/events/Workshop\% 20ISWA\%20-\%20EXPRA\%20-\%20RDN_summary.pdf (accessed March 22 2016)

Fernandez, L \& Ruberto C (2008) Raccoglitori di residui-Una panoramica globale del pri mo anello del circuito del riciclaggio Reorient-Retos al Sur. St Gallen, Switzerland, the Collaborative Working Group on Solid Waste Management in Low- and Middle-income Countries (CWG).

Gille, Z (2007) From the Cult of Waste to the Trash Heap of History: The Politics of Waste in Socialist and Postsocialist Hungary. Bloomington, Indiana, USA, Indiana University Press.

Godfrey, L (2014) A Vision Of Zero Packaging To Landfill By 2030: Packaging and Paper Industry Waste Management Plan, Draft Proposal for Discussion with the DEA, September 2014. Johannesburg, South Africa, PACSA, Packaging Council of South Africa.

Gunsilius, E , Chaturvedi B \& Scheinberg A (2011) The Economics of the Informal Sector in Solid Waste Management. Eschborn, Germany, Deutsche Gesellschaft für Internationale Zusammenarbeit (GIZ) GmbH and St Gallen, Switzerland, Collaborative Working Group on Solid Waste Management in Low- and Middle-income Countries (CWG). Available from www.GIZ.de publications (accessed March 2016).

Gutberlet, J (2008). Organized and informal recycling: social movements contributing to sustainability. IWaste Management and the Environment IV, pp. 223-230.

Gutberlet, J, Kain J, Nyakinda B, Ochieng D H, Odhiambo N, Oloko N, Omolo J, Omondi E, Otieno S, Zapata P and Zapata Campos M J (2016) Socio-environmental entrepreneurship and the provision of critical services in informal settlements. Environment and Urbanization 28 (6) pp 205-222.

International Finance Corporation (IFC) (2008) The IFC Recycling Linkages Programme. Presentation given at the CWG Workshop in Cluj-Napoca, Romania, February 20-22, 2008. Available at www.greenpartners.ro (downloaded July 13 2012).

International Finance Corporation (IFC) (2010) IFC Advisory Services in Environmental and Social Sustainability, Annual Report for 2009. Washington, DC. USA, International Finance Corporation. Available at: http://www.ifc. $\mathrm{org} / \mathrm{wps} / \mathrm{wcm} / \mathrm{connect} / \mathrm{ifc}$ _ext_design/ifc+search/search/Search+Results+2015UI?cx=009183910618791464029\%3 Aik2jtgcdpms\&cof=FORID\%3A11\&ie=\&q=PEP+SE+Recycling+Linkages (accessed January 2016).

International Labour Organization (ILO) (2004) Addressing the Exploitation of Children in Scavenging: a Thematic Evaluation of Action on Child Labour. A Global Synthesis Report for the ILO. Geneva, Switzerland, International Labor Organization (ILO). http://www.ilo.org/Search4 (accessed January 27 2016)

International Labour Organization (ILO) (2013) Sustainable development, decent work and green jobs. Proceedings of the 102nd Session of the International Labour Conference, Report V, Geneva,. Switzerland, International Labor Organization (ILO), June 2013.

Ishengoma, A (2006) Employment creation in municipal service delivery in Eastern Africa: Improving living conditions and providing jobs for the poor 2003-2005. Programme Report of the combined programmatic initiatives of ILO-Small Enterprise Development (PPP), ILO-Employment- Intensive Investment Programme, ILO/ASISTAfrica, ILO Sub Regional Office, Addis Ababa, ILO-IPEC Tanzania. Geneva, Switzerland, International Labor Organization (ILO).

Iskandar, L and Shaker B (2007 (updated 2010) Cairo City Report and Spreadsheets. Research report used in preparation of Scheinberg et al 2010b. Available from GIZ reports (2016) Eschborn, Germany, German International Co-operation (GIZ). https://www.giz.de/expertise/downloads/gtz2010-en-Economic-AspectsWASTE.pdf (accessed February 2 2016).

Iskandar, L R K (1994) Mokattam Garbage Village. Cairo, Egypt, Stallion Graphics.

ITUC (2014) The Informal Recycling Sector - Context, Frameworks, Policies. Brussels, Belgium, ITUC, the International Trade Union Confederation.

King, M F, and Gutberlet J (2013) Contribution of cooperative sector recycling to greenhouse gas emissions reduction: A case study of Ribeirão Pires, Brazil. Waste Management 33(12) pp. 2771-2780.

Kozák, J (2012) Organising used items collectors in Hungary, the International Second Hand Service - ISHS. In: Trans-Boundary Re-Use Trade In Central Europe: Papers from the TransWaste Project Final Conference, 
Budapest, Hungary, 24-25 September 2012. Available at: www.transwaste.eu , final conference (accessed February 28 2016).

Len, M (2012) Boosting re-use rates in Europe. Presentation given at the TransWaste Final Conference, September 2012. Vienna, Austria. BOKU, Institute of Waste Management University of Natural Resources and Life Sciences. Available at http://www.transwaste.eu/file/001641.pdf (accessed March 19 2016).

Len, M (2014) Approved Re-use Centres and Networks - Principles. Statement on behalf of RREUSE, the Network of European Re-use Organisations. Available from http://www.rreuse.org/wp-content/uploads/RREUSE_approved_ reuse_centre_principles.pdf (accessed April 5, 2016).

Linzner, R (2012) Contextualising TransWaste in the Global Waste Picker Integration Discourse. Presentation given at the TransWaste Final Conference, September 2012. Vienna, Austria. BOKU, Institute of Waste Management University of Natural Resources and Life Sciences. Available at http://www.transwaste.eu/file/001641.pdf (accessed March 19 2016).

Linzner, R \& Lange U (2013) Role and size of informal sector in waste management - a review. WASTE Resource Management - ICE Proceedings, 166 (2), 69-83; ISSN 1747-6526.

Linzner, R, Scherhaufer S, Obersteiner G, Kabosch U, Kobler A \& Stix S (2011) Formalisation Options for Informal Sector Activities and their Legal Requirements in Central Europe. Paper delivered at the Thirteenth International Waste Management and Landfill Symposium, Sardinia 2011. Vienna, Austria BOKU, Institute of Waste Management, University of Natural Resources and Life, Sciences. See also http://www.transwaste.eu (accessed January 15 2016).

Lobo Ugalde, S, Marín Araya M. Salas, F \& Rudin Vega V (2016) Análisis de los retos para el desarrollo de la Cadena de Valor del Reciclaje en Centroamérica, Informe final. (English translation entitled: Analysis of Challenges in Development of the Recycling Value Chain in Central America, Final Report). Regional Initiative for Informal Recycling (IRR), Washington D.C., USA, InterAmerican Development Bank.

Luppi P (2006) Tutto da Rifare. Milan, Italy, Edizioni Terre di Mezzo

Luppi, P \& Sole E (2015) Il Salto della Pulce. Chapter 5, pp. 104 - 120. Milan, Italy, Edizioni Altreconomia, http://www.altreconomia.it/site/ec_articolo_dettaglio.php?intId=287. (Accessed March 28, 2016).

Luppi, P, \& Vergalito, E (2013) Los Procesos de Integración de Las Economías Populares En La Gestión De Residuos. Panorámica General Con Enfoque En América Latina Y Europa. Instituto Latino de Cooperación Técnica y Científica, Roma, Italia.

Medina, M (1997) Informal Recycling and Collection of Solid Wastes in Developing Countries: Issues and Opportunities. UNU/IAS Working Paper 24, Tokyo, Japan, The United Nations University/Institute of Advanced Studies.

Medina, M (2009) Global Supply Chains in Chinese and Indian Industrialization: Impact on Waste Scavenging in Developing Countries UNU/WIDER Working Paper, Tokyo, Japan, The United Nations University/Institute of Advanced Studies.

Melosi, M (1981) Garbage in the Cities, Refuse, Reform and Environment, 1880-1980. College Station, Texas USA.Texas A\&M Press.

Mendonça, M M T (2015) The Informal Waste Sector in the Metropolitan Area of Pristina, Kosovo.: Potentials and Challenges for the Improvement of the Socio-Economic Situation of Waste Pickers. Master of Science thesis. Berlin, Germany, Technische Universität Berlin.

Ministry of Environment and Climate Changes of Romania and The National Environmental Protection Agency (2014) National Report on the State of the Environment in 2013. Available at: http://www.anpm.ro/documents/ 12220/2209838/R+S+M+2013+engleza.pdf/daba6dd0-a84b-4973-a14d-e0964d4a0076 (accessed April 18, 2016).

Newman, D (2015) "ISWA launches CSR-project to help scavenger kids" Column by David Newman, ISWA President, 14 September 2015. http://www.iswa.org/media/publications/presidents-blog/ (accessed 15 September 2015).

Obersteiner, G, et al (2012) Website of the TransWaste programme, 2009-2012. Vienna, Austria. BOKU Institute, University of Natural Resources and Life Sciences. All workshops and all reports available at www.transwaste.eu (accessed on March 25 2016).

Occhio del Riciclone (2006) Il Settore dell'usato nella gestione dei rifiuti. Available at: www.occhiodelriciclone.com (accessed September 3, 2015)

Occhio del Riciclone (2008) Impatti di un riuso sistemico nella cittá di Roma. Available at: http://www.occhiodelriciclone.com/index.php?option=com_content\&view=article\&id=153:impatti-occupazionalidi-un-riuso-sistemico-nella-citta-di-roma-2008\&catid=38:studi\&Itemid=42 (accessed March 31 2016)

Occhio del Riciclone (2009) La Seconda Vita delle Cose, Appendix II, pp.176-178. Milan, Italy. Edizioni Ambiente, http://www.edizioniambiente.it/libri/323/la-seconda-vita-delle-cose/ (accessed March 15 2016)

Occhio del Riciclone (2015) Roma: Analisi dei flussi stimati di beni avviabili a riuso e del loro mercato potenziale. Rome, Italy. Not available online, for the pdf please contact AMA S.p.a. 
Occhio del Riciclone \& Associazione Operatori Porta Portese (2006) Manifesto del Riuso. Rome, Italy. Available at: http://www.occhiodelriciclone.com/attachments/187_Manifesto\%20del\%20Riuso.pdf (accessed March 15 2016)

Occhio del Riciclone, Italian Environment Ministry (2011) Rapporto Nazionale sul Riutilizzo , pp 64-71. Rome. Italy. Available at: http://www.redattoresociale.it/documenti/RAPPORTO\%20NAZIONALE\%20SUL\%20RIUTILIZZO\% 202011.pdf (accessed March 15 2016).

OECD (2016, in press) Extended Producer Responsibility, A Guidance Manual for Governments. Paris, France, Organisation for Economic Cooperation and Development (OECD).

Oyake-Ombis, L (2012) Managing Plastic Waste in Urban Kenya, Niche Innovations in Production and Recycling. $\mathrm{PhD}$ Dissertation, Wageningen, the Netherlands, Wageningen University and Research Centre. Available at: http://library.wur.nl/WebQuery/wurpubs/ fulltext/239452 (accessed April 3 2016)

Petean, F \& Pop F (2015) Aluminum Value Chain Study by Green Partners. Vienna, Austria. BOKU institute, University of Natural Resources and Life Sciences.

Popovska, V, Gribizi I \& Georgievska A (2008) Waste Pickers: Recycling Linkages Program Western Balkans. Washington D.C. USA, International Finance Corporation. Available at: http://siteresources.worldbank.org/ INTUSWM/Resources/463617-1211490261972/Popovska-Gribizi-Georgievska.pdf. (Accessed April 4 2016)

Porter, M (2012) Recycling from the Margins: Informal Recycling Networks in St. John's as Social Interactions. St. Johns, British Colombia. The Leslie Harris Centre for Regional Policy and Development And the Multi-Materials Stewardship Board.

Poulussen, P (1987) Van Burenlast tot Milieuhinder: het stedelijk leefmilieu 1500-1800. Kapellen, Belgium. DNB/Uitgeverij Pelckmans,.

Ramusch R (2015): Measuring informality? Challenges in quantifying informal recycling sector activities. $\mathrm{PhD}$ Dissertation, Vienna. Austria. Department Water-Atmosphere-Environment, Institute of Waste Management, University of Natural Resources and Life Sciences. Available at: http://media.obvsg.at/AC10778353 (accessed March 31 2016).

Ramusch, R \& Obersteiner G (2012), Trans-Boundary Re-Use Trade In Central Europe: Papers from the TransWaste Project Final Conference, Budapest, Hungary, 24-25 September 2012. Final Conference section of the TransWaste project website, www.transwaste.eu, (accessed February 3 2016)

Ramusch, R, Pertl A, Scherhaufer S, Schmied S, Obersteiner G. (2015) Modelling informally collected quantities of bulky waste and reusable items in Austria. Waste Management 2015 Oct, 44:3-14. doi: 10.1016/j.wasman.2015. 07.015. Epub 2015 Jul 21.

Romanian Ministry of Environment and Forests (2013) Date privind ambalajele introduse pe piaţă şi deşeurile de ambalaje gestionate în anul 2012. Available at: http://www.anpm.ro/ documents/12220/2023814/Interpretarea+ datelor+raportate+pentru+ambalaje+si+deseuri+de+ambalaje+2012.pdf/72d046ab-89de-45a8-bdd3-2d224ceae2d8 (accessed April 18, 2016).

Rome City Hall Council (2005) Ordine del giorno 45 del 12/5/2005 del Consiglio Comunale di Roma. Rome, Italy. Available at: http://www.occhiodelriciclone.com/attachments/189_Odg\%2045\%20del\%2012-5-2005\%20Comune \%20Roma.pdf (accessed March 31 2016)

Rutkowski J \& Rutkowski E (2015). Expanding Worldwide Urban Solid Waste Recycling: The Brazilian Social Technology in Waste Pickers Inclusion. Waste Management and Research vol. 33, 12: pp. 1084-1093. Online First on October 14, 2015

Samson, M (ed) (2009) Refusing to be Cast Aside: Waste Pickers Organising Around the World.. WIEGO (Women in Informal Employment: Globalising and Organising) Cambridge, Massachusetts, USA. Available at www.wiego.org (accessed March 23 2014)

Scheinberg, A (2011) Value Added: Modes of sustainable recycling in the modernisation of waste management systems. Ph.D. Thesis, Wageningen University.

Scheinberg, A \& Anschütz J (2006) Slim Pickin's: Supporting Waste Pickers in the Ecological Modernisation of Urban Waste Management Systems. International Journal of Technology Management and Sustainable Development 5(3): pp. 257-70

Scheinberg, A \& IJgosse J (2004) Waste Management in the Netherlands. Report Prepared for UNITRABALHO, Recife, Brazil. WASTE, The Netherlands, www.waste.n

Scheinberg, A \& Mol A P J (2010) Multiple Modernities; transitional Bulgaria and the ecological modernisation of solid waste management. Environment and Planning C 28(1): pp. 18-36.

Scheinberg, A \& Nesić J (2014) Engaging Informal Recyclers in Europe: Status and Report of a Consultation. Paper number 507, ISWA World Congress, São Paolo, Brazil, September 2014. Available from the authors.

Scheinberg, A \& Savain R (2015) Valuing Informal Integration: Inclusive Recycling in North Africa and the Middle East. Eschborn, Germany, Deutsche Gesellschaft für Internationale Zusammenarbeit (GIZ) GmbH. Available from http://wiego.org/publications/valuing-informal-integration-inclusive-recycling-north-africa-and-middle-east 
Scheinberg, A Haenen A, Nesić J, Mitrović A (2012) Fair Waste Practices. Final Report of the MATRA-financed project in South Serbia. Gouda, the Netherlands, WASTE, Advisers on Urban Environment and Development. Not available online, contact the first and second authors of this paper for the pdf.

Scheinberg, A, Mitrović A, \& Post V (2007) Assessment Report: Needs of Roma Collectors and Other Stakeholders in the PEP SE Region for Training, Technical Assistance, and Financial Services and Recommendations for Programmatic Response. Recycling Linkages Private Enterprise Programme South East Europe (PEP SE). Washington DC USA, International Finance Corporation.

Scheinberg, A, Simpson, M H \& Gupt Y (2010b) Economic Aspects of the Informal Sector in Solid Waste Management Main Report. From GIZ reports (2016) Eschborn, Germany, German International Co-operation (GIZ). https://www.giz.de/expertise/downloads/gtz2010-en-Economic-Aspects-WASTE.pdf (accessed February 2 2016)

Scheinberg, A, Wilson DC \& Rodic L (2010a) Solid Waste Management in the World's Cities. UN-Habitat's Third Global Report on the State of Water and Sanitation in the World's Cities. Newcastle-on-Tyne, UK Earthscan Publications.

Schmied, E, Scherhaufer S, Obersteiner G, Kabosch U, Kobler A; S. Stix S (2011) Formalisation Options For Informal Sector Activities And Their Legal Requirements In Central Europe. Paper delivered at the Thirteenth International Waste Management and Landfill Symposium, Sardinia 2011. Institute Of Waste Management, University Of Natural Resources And Life Sciences, Vienna, Austria. Available at the TransWaste project website, www.transwaste.eu, (accessed February 3 2016).

Sim, N, Wilson D C, Velis C, \& Smith S (2013) Waste management and recycling in the former Soviet Union - Case study of Bishkek, Kyrgyz Republic (Kyrgyzstan). Waste Management and Research 2013 (10 Suppl): pp. 106-25. Also available at: https://www.researchgate.net/publication/258200465_Waste_management_and_recycling _ in_the_former_Soviet_Union_The_City_of_Bishkek_Kyrgyz_Republic_Kyrgyzstan (accessed February 27 2016).

Simpson-Hébert, M, Mitrović A, Zajić G, Petrović M (2005) A Paper Life, WEDC, , Loughborough, UK, Loughborough University.

Simpson, M H (1993) Lapaks and Bandars Convert MSW in Indonesia. Biocycle, June 1993.

Soos R, \& Popoviçi C (2007) Cluj-Napoca City Report and Spreadsheets. Research report used in preparation of Scheinberg et al 2010b. Available from GIZ reports (2016) Eschborn, Germany, German International Co-operation (GIZ). https://www.giz.de/expertise/downloads/gtz2010-en-Economic-Aspects-WASTE.pdf (accessed February 2 2016)

Soos R, \& Popoviçi C (2008) Planning In the Real World, Challenges of Sustainable and Affordable Modernisation in the Solid Waste Sector. Report of the CWG International workshop, Cluj-Napoca, Romania, 22 and 23 February, 2008. Cluj-Napoca, Romania, Green Partners. Available at www.greenpartners.ro, (accessed May 17 2012)

Soos, R, Briciu E C, Abdeljaoud I, Zin al Abidine K, Thaly D, \& Ghribi A (2014) Final Report, Structural Integration of the Informal Sector into the Municipal Solid Waste Management in Tunisia. German Federal Ministry for Economic Cooperation and Development through the Fund for Good Governance in the MENA Region. http://www.sweep-net.org/activities/structural-integration (accessed November 2, 2015)

Springloop Cooperatie (2016, in preparation). Report of the Antwerp European Waste Pickers Meeting, Bourla Schouwburg, 7 September 2016. Pending availability at www.springloop.nl (expected May 2016). Information also available from the authors of this paper.

Swaan, A de (1988) In Care of the State, Health Care, Education and Welfare in Europe and the USA in the Modern Era. Cambridge, UK., Polity Press,

Tasheva, E (2012) Presentation on Recycling in Bulgaria, given at the TransWaste Closing Meeting in Budapest, September 2012. www.TransWaste EU, Meetings, Final Workshop 2012 (accessed January 2015)

Torino City Hall \& Rete Onu (2016) Sgravi fiscali agli operatori dell'usato che contribuiscono alla riduzione dei rifiuti. Torino, Italy. Available at: http://www.comune.torino.it/ucstampa/comunicati/article_222.shtml (accessed March 15 2016)

Toska A , Tikvesanski A \& Lazarov A (2012) USAID Plastic Recycling Project Phase 1. From USAID website, http://plasticrecycling.org.mk. Accessed March 312016.

Toska A \& Lazarov A (2007) USAID and the Municipality of Kocani initiate a successful plastic recycling program. http://macedonia.usembassy.gov/uploads/images/s-

Fq_CnNY87oygZADgtN9w/prKocaniRecyclingProgramENG.pdf. Accessed March 312016.

Vaccari, M, Di Belli,V, Vitali F, Collivignarelli C (2013) From mixed to separate collection of solid waste: Benefits for the town of Zavidovic i (Bosnia and Herzegovina). Waste Management 33 pp. 277-286

Velis C A., Wilson D C and Cheeseman C R (2009) 19th century London dust-yards: a case study in closed-loop resource efficiency. Waste Management 29, pp. 1282-1290.

Velis, C A, Wilson D C, Rocca, O, Smith S R, Mavropoulos A \& Cheeseman C R (2012) An analytical framework and tool ('InteRa') for integrating the informal recycling sector in waste and resource management systems in 
developing countries. Waste Management Research 2012 30: pp. 43-46. The online version of this article can be found at: http://wmr.sagepub.com/content/30/9_suppl/43.

Whiteman, A D (2008) Implementing EU waste management directives at the local level in Bulgaria. Presentation given at the CWG Workshop Solid Waste Management Planning in the Real World in Cluj-Napoca, Romania, February 2008. Green Partners, Romania,. Available at www.cwgnet.net and www.greenpartners.ro (accessed March 17 2016).

Whiteman, A D Doychinov, N \& Soos, R (2009) Evaluation of the Recycling Linkages Programme in the Western Balkans. Washington, DC USA, International Finance Corporation.

WIEGO (Women in Informal Employment Globalizing and Organizing) (2009) South Africa's Informal Economy: A Statistical Profile. Urban Policies Research Report, No. 7 April 2009. Available at http://wiego.org/sites/wiego. org/files/publications/files/Wills_WIEGO_WP6.p df [accessed 20 August 2013].

Wilson D.C.; Araba A.O.; Chinwah K. and Cheeseman C.R. (2009): Building recycling rates through the informal sector. Waste Management 29(2): 629-635.

Wilson, D C et al. (2015) The Global Waste Management Outlook. Nairobi, Kenya, United Nations Environmental Programme (UNEP).

Wilson, D C, Scheinberg A, Rodic L (2010) Comparative Analysis Of Waste Management In 20 Cities. Waste Management \& Research 30(3) 237-254

Wilson, D C, Velis, C, Cheeseman C R (2006) Role of informal sector recycling in waste management in developing countries. Habitat International 30, 797-808.

Zambryzcki, B (2013) EU policy on organic resources and biowaste recycling in Europe - Challenges by implementing the Waste Framework Directive and the target review process. Presentation given at the European Biowaste Seminar, Poznań, Poland, 8 October 2013

Zero Waste Europe (2015) Redesigning Producer Responsibility: A new EPR is needed for a circular economy. Brussels, Belgium and Amsterdam, the Netherlands, September 2015. Available at: http://www.zerowasteeurope. eu/downloads/redesigning-producer-responsibility-a-new-epr-is-needed-for-a-circular-economy (accessed February 18 2016).

\section{Acknowledgements:}

The authors would like to thank the peer reviewers for their extensive, skillful, and extremely constructive criticism. If this paper makes it into the special issue, a substantial amount of the credit goes to those anonymous colleagues.

In addition, the authors, all of whom were involved in the Antwerp meeting, would like to acknowledge and appreciate the positive support of the following European organisations in breaking the taboos around talking about the European Informal sector:

- WIEGO, Women in the Informal Economy, Globalising, Organising, for the collegial support of Lakshmi Narayan, and their financial contribution to Engaging Informal Recyclers in Europe, a predecessor initiative to this Review

- OdR, Occhio di Riciclone, and RETE Onu, the network of re-use operators in Italy;

- SKAT, the Swiss Resource Centre and Consultancies for Development, both for the direct support to the Antwerp meeting, and for their long service as the secretariat of the CWG;

- EXPRA, the EXtended Producer Responsibility Alliance, to Joachim Quoden, its director, and Alphan Eröztürk, its Chairman of the Board, and Monika Romenska, long-suffering staff, for being the first European EPR organisation to dare to raise the issue of informal recycling;

- Zero Waste Europe, for letting the informal sector play a modest role in the articulation of their global vision of a waste-free world; and

- Roland Ramusch (né Linzner) of BOKU in Vienna, who, together with his TransWaste colleagues, is making a disproportionate but very welcome contribution to the literature by publishing articles based on the rich experience of the TransWaste project, and who is also very fast and very helpful in sharing materials and information.

- Our friends and colleagues in the CWG, who support the work on European Informal Recyclers with energy, inspiration, humour, and a strong commitment to community of practice. 


\section{OD SUKOBA DO SARADNJE - INTEGRACIJA NEFORMALNIH RECIKLERA I OPERATORA PONOVNOG KORIŠĆENJA OTPADA U EVROPI: PREGLED}

Evropska unija ima jedan od najrazvijenijih sistema upravljanja otpadom na svetu i ambiciozno postavljenu politiku cirkularne (kružne) ekonomije. Postojanje neformalnih oblika reciklaže, tretiranja $i$ ponovnog korišćenja otpada u Evropi je do nedavno osporavano, tako da ove aktivnosti $i$ dalje predstavljaju veliki izazov za evropski sektor upravljanja čvrstim otpadom, kao i za evropske vlade $i$ privatne institucije. U mnogim zemljama Evropske unije, od Malte do Makedonije, od Francuske do Turske, neformalni recikleri (sakupljači i prerađivači otpada) su potpuno isključeni iz reciklažnog sektora, pa se sve više suočavaju i sukobljavaju sa prilično formalizovanim i kontrolisanim pristupom koji Evropska unija ima u pogledu upravljanja otpadom u urbanim sredinama, programa za reciklažu ambalaže, formalnih preduzeća za preradu otpada i proširenih sistema odgovornosti proizvođača.

Ovaj rad pokriva period od 2004. godine do prve polovine 2016. godine. U radu se daje pregled 78 dokumenata koji regulišu pitanje neformalne reciklaže $i$ prerade otpada u Evropskoj uniji $i$ susednim državama, u kontekstu globalnih smernica i iskustava. Nakon pregleda izvora koji se odnose na neformalne vidove reciklaže u Evropskoj uniji $i$ na granicama Evropske unije, $u$ radu se evidentiraju sporna pitanja $i$ sukobi nastali $u$ ovoj oblasti, $i$ prikazuju neki konstruktivni pristupi legalizaciji, integraciji i pomirenju sukobljenih strana. Ključne preporuke u pogledu adekvatnog pozicioniranje pitanja neformalnih vidova reciklaže i njihovog uključivanja u Evropski paket mera za uvođenje kružne ekonomije nedvosmisleno su utvrđene u okvirima četiri stuba strategije integracije: dokumentacija, legalizacija, priznavanje zanimanja $i$ preduzeća, $i$ priprema za strukuralnu integraciju.

Ključne reči: neformalna reciklaža i ponovna upotreba otpada, Evropa, cirkularna (kružna) ekonomija, Balkan i nova EU, neformalna integracija, proširena odgovornost proizvođača. 